University of Nebraska - Lincoln

DigitalCommons@University of Nebraska - Lincoln

$11-13-2017$

\title{
Late Quaternary uplift along the North America-Caribbean plate boundary: Evidence from the sea level record of Guantanamo Bay, Cuba
}

Daniel R. Muhs

Eugene S. Schweig

Kathleen R. Simmons

Robert B. Halley

Follow this and additional works at: https://digitalcommons.unl.edu/usgsstaffpub

Part of the Geology Commons, Oceanography and Atmospheric Sciences and Meteorology Commons, Other Earth Sciences Commons, and the Other Environmental Sciences Commons

This Article is brought to you for free and open access by the US Geological Survey at DigitalCommons@University of Nebraska - Lincoln. It has been accepted for inclusion in USGS Staff -- Published Research by an authorized administrator of DigitalCommons@University of Nebraska - Lincoln. 


\title{
Late Quaternary uplift along the North America-Caribbean plate boundary: Evidence from the sea level record of Guantanamo Bay, Cuba
}

\author{
Daniel R. Muhs", Eugene S. Schweig, Kathleen R. Simmons, Robert B. Halley \\ U.S. Geological Survey, MS 980, Box 25046, Federal Center, Denver, CO 80225, USA
}

\section{A R T I C L E I N F O}

\section{Article history:}

Received 5 January 2017

Received in revised form

13 October 2017

Accepted 17 October 2017

Available online 13 November 2017

\section{Keywords:}

\section{Pleistocene}

Sea level changes

North Atlantic

U-Th series

Geomorphology

Coastal

Cuba

Uplift

\begin{abstract}
A B S T R A C T
The tectonic setting of the North America-Caribbean plate boundary has been studied intensively, but some aspects are still poorly understood, particularly along the Oriente fault zone. Guantanamo Bay, southern Cuba, is considered to be on a coastline that is under a transpressive tectonic regime along this zone, and is hypothesized to have a low uplift rate. We tested this by studying emergent reef terrace deposits around the bay. Reef elevations in the protected, inner part of the bay are $11-12 \mathrm{~m}$ and outercoast, wave-cut benches are as high as $\sim 14 \mathrm{~m}$. Uranium-series analyses of corals yield ages ranging from $\sim 133 \mathrm{ka}$ to $\sim 119 \mathrm{ka}$, correlating this reef to the peak of the last interglacial period, marine isotope stage (MIS) 5.5. Assuming a span of possible paleo-sea levels at the time of the last interglacial period yields long-term tectonic uplift rates of $0.02-0.11 \mathrm{~m} / \mathrm{ka}$, supporting the hypothesis that the tectonic uplift rate is low. Nevertheless, on the eastern and southern coasts of Cuba, east and west of Guantanamo Bay, there are flights of multiple marine terraces, at higher elevations, that could record a higher rate of uplift, implying that Guantanamo Bay may be anomalous. Southern Cuba is considered to have experienced a measurable but modest effect from glacial isostatic adjustment (GIA) processes. Thus, with a low uplift rate, Guantanamo Bay should show no evidence of emergent marine terraces dating to the $\sim 100 \mathrm{ka}$ (MIS 5.3 ) or $\sim 80 \mathrm{ka}$ (MIS 5.1) sea stands and results of the present study support this.
\end{abstract}

Published by Elsevier Ltd.

\section{Introduction}

The complex boundary between the North America plate and the Caribbean plate at its northern margin (Fig. 1) is considered to be primarily a left-lateral, strike-slip zone, $\sim 100-\sim 250 \mathrm{~km}$ wide, that extends over a distance of $\sim 2000 \mathrm{~km}$ (Fig. 1). East of the spreading zone near the Cayman Islands, the plate boundary is dominated by two main subparallel faults, the Enriquillo-Plantain Garden fault zone (often called the "EPGFZ") in the south and the Oriente-Septentrional fault zone in the north (Fig. 2; note that just the Oriente portion of the Oriente-Septentrional fault zone is shown here). The North America-Caribbean plate boundary is seismically active and has been studied intensively (Calais et al., 1998; Mann, 2007; Mann et al., 1995, 2002; Pindell and Kennan, 2009; Prentice et al., 2010). Mann et al. (2002), using Global Positioning System (GPS) measurements, infer that the rigid interior of

\footnotetext{
* Corresponding author.

E-mail address: dmuhs@usgs.gov (D.R. Muhs).
}

the Caribbean plate is moving northeastward, but rates of horizontal movement vary among individual crustal blocks within the plate, ranging from 19 to $20 \mathrm{~mm} / \mathrm{yr}$ (e.g., Puerto Rico) to $4-17 \mathrm{~mm} /$ yr (e.g., Dominican Republic). Although much of the movement along the northern plate boundary is known to be horizontal, detailed studies have shown that vertical movement is also a component of Quaternary tectonics, and late Quaternary uplift rates vary significantly along its length. For example, Mann et al. (1995), studying the emergent, 120 ka coral reef terraces in Haiti, report that uplift rates vary from $\sim 0.37 \mathrm{~m} / \mathrm{ka}$ in the northwestern peninsula, to $\sim 0.19 \mathrm{~m} / \mathrm{ka}$ in the western part of Haiti, to zero in the south-central part of western Haiti, on Gonave Island. Higher uplift rates in some areas may be due to restraining bends in the major strike-slip faults that accommodate movement along the North America-Caribbean plate boundary (Mann, 2007).

To the west of Haiti, movement along the North AmericaCaribbean plate boundary is accommodated primarily by the Oriente fault zone, which parallels the southern coast of Cuba (Fig. 2). Rojas-Agramonte et al. (2005) proposed that the Oriente fault zone has undergone considerable evolution over time, from a region 


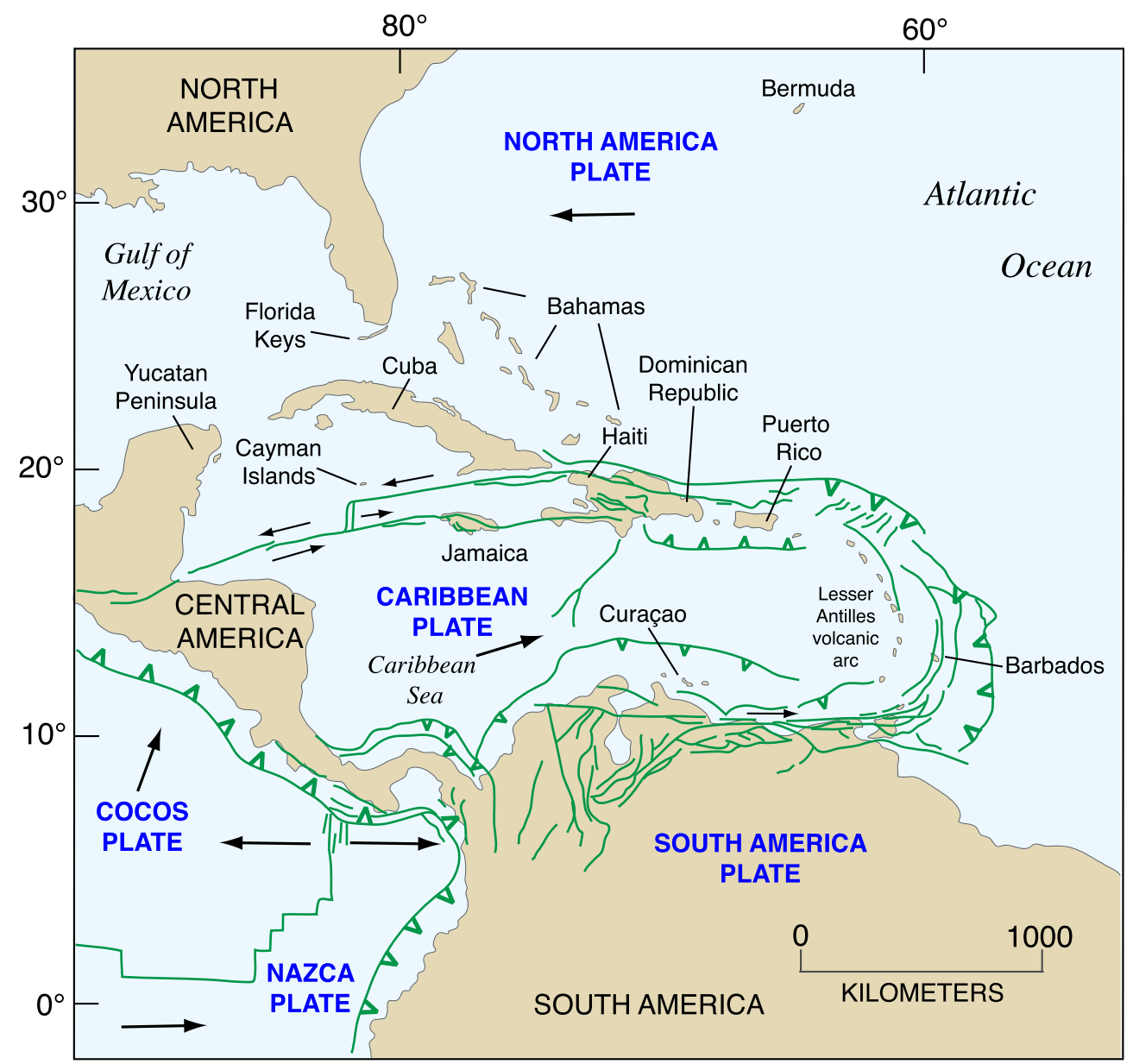

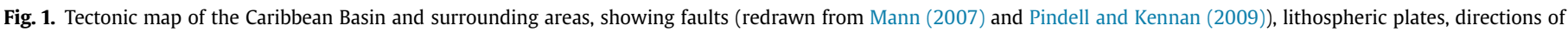
present plate movements (arrows), and localities referred to in text.

dominated by compression (late Eocene-Oligocene), to transtension (late Oligocene to Miocene [?]), to transpression (Pliocene to present), when the region had fully evolved into a transform fault zone. If the Oriente fault zone is now characterized by transpression, there should be a measurable component of vertical movement, although possibly small. Such a vertical component of movement could be expressed as uplifted, wave-cut marine terraces or uplifted, constructional coral reef terraces, similar to what Mann et al. (1995) report for Haiti.

Going back more than a century, early investigators noted the presence of emergent coral reef terraces on the coasts of Cuba, but struggled with interpretations of whether these landforms represented uplift, subsidence, or both (Agassiz, 1894; Crosby, 1882; Hill, 1895; Vaughn, 1919). Part of the frustration for these pioneering scientists in interpreting the Cuban terraces was likely due to Darwin's (1889, with earlier editions in 1842 and 1874) theory of coral reef formation, which posits that coral reefs form as a result of long-term regional subsidence. Thus, the presence of emergent coral reef terraces on the coast of Cuba, sometimes at considerable elevation, was difficult for early investigators to reconcile with long-term subsidence.

Later investigators provided new hypotheses about the terraces of southern Cuba. Taber (1934) studied a flight of 12 terraces situated $22 \mathrm{~km}$ to the east of Cabo Cruz (Fig. 2). He considered that the terraces in southern Cuba were erosional, wave-cut features, rather than constructional reef terraces, but he recognized that the highest of these terraces (at least $\sim 300 \mathrm{~m}$ above present sea level) were too high to be explained by eustatic sea-level rise from any Pleistocene interglacial period. Thus, he concluded that there must have been Quaternary uplift and in fact offered the possibility that the lowest terrace in southern Cuba could even be of Holocene age, implying a relatively high rate of uplift. Taber (1934) inferred that each terrace represented a discrete, presumably coseismic, uplift event. A few decades later, Horsfield (1975), in a pan-Caribbean review of marine terrace records, also noted that a detailed marine terrace record is present along the southern coast of Cuba. Consistent with modern concepts of marine terraces and sea level history, however, he recognized that each terrace likely represented an interglacial high-sea stand, rather than a discrete coseismic event. Horsfield (1975) hypothesized that the numbers of terraces and the altitudes of the highest terrace were positively correlated with uplift rate. Thus, by these criteria, Horsfield (1975) inferred that along the eastern Cuban coast, uplift rates would be highest near Punta de Maisí (Fig. 2), where his estimates of the number of terraces was greatest and terrace elevations are highest. He speculated that uplift rates should decrease to the west, toward Cabo Cruz. More recently, Rojas-Agramonte et al. (2005) reported marine terraces at elevations up to $200 \mathrm{~m}$ in the Santiago area of southern Cuba (Fig. 2), and inferred that these landforms must have been elevated by tectonic uplift. Because of the relatively high elevations of some of the terraces in this part of Cuba, Rojas-Agramonte et al. (2005, p. 177) interpreted the southeastern part of the island to be experiencing a high rate of tectonic uplift.

It is important to point out, however, that in the absence of 


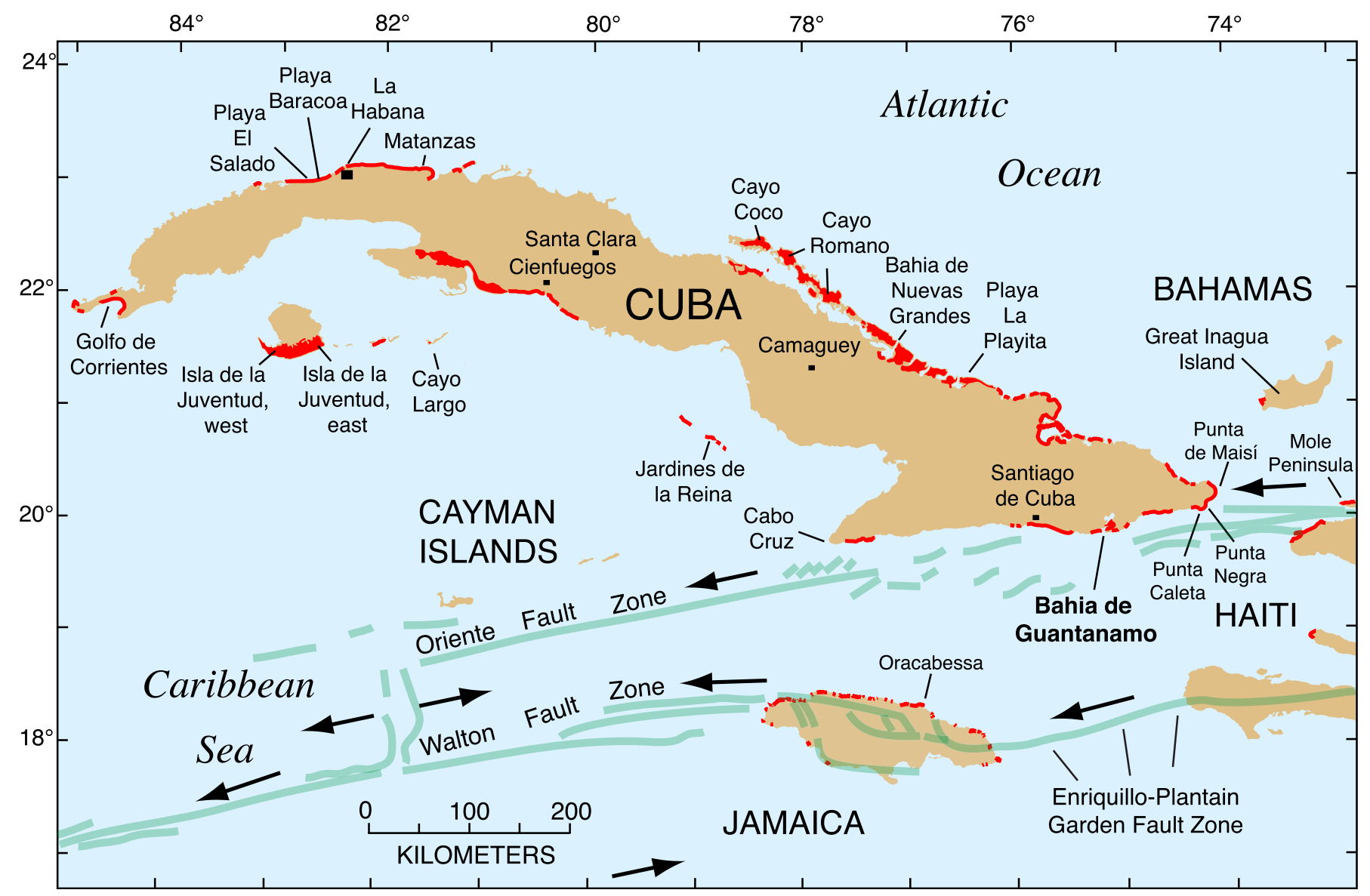

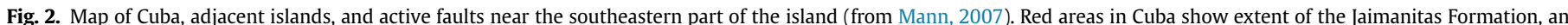

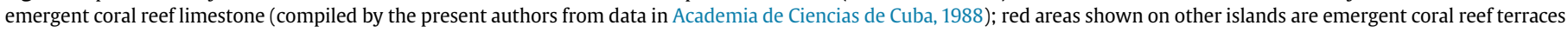

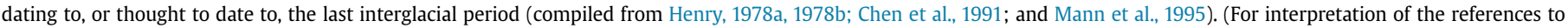
colour in this figure legend, the reader is referred to the web version of this article.)

terrace ages, numbers of terraces and their elevations are not necessarily reliable indicators of uplift rates. For example, the northwest coast of Haiti and the Huon Peninsula of New Guinea both host about 20 uplifted reef terraces, but their uplift rates, based on the age and elevation of the 120,000 -yr-old terrace, differ by as much as a factor of seven (Bloom et al., 1974; Dodge et al., 1983). Part of the explanation for the difference between the geomorphic record of Haiti and New Guinea may be related to the potential for preservation. On New Guinea, older terraces, perhaps of the same age as the highest ones on Haiti, may once have existed, but with higher rainfall, erosional removal of old landforms is much more likely. Along coastlines with similar climates, where preservation potential might be approximately equal, greater numbers of terraces and terraces at higher elevations likely do have some tectonic significance, as hypothesized by Horsfield (1975).

Regional-scale mapping by Cuban geologists (Academia de Ciencias de Cuba, 1988) indicates that the lowest-elevation marine terrace of Cuba could be broadly of the same age along its length and is a constructional coral reef terrace, rather than an erosional landform. The limestone of which this terrace is composed is referred to as the Jaimanitas Formation (Cabrera and Peñalver, 2001; Portell et al., 2008, 2009; Rojas-Agramonte et al., 2005; Toscano et al., 1999). This formation is widespread around much of the coastline of Cuba (Fig. 2). In the Havana (La Habana) area (Fig. 2), Toscano et al. (1999) reported three U-series ages of corals that indicate that at least in this part of Cuba, the Jaimanitas Formation could date to the last interglacial period, $\sim 120 \mathrm{ka}$. The Jaimanitas Formation in the Havana area is only $1 \mathrm{~m}-3 \mathrm{~m}$ above sea level (Toscano et al., 1999). Rojas-Agramonte et al. (2005) mapped the formation along reaches of the southern Cuban coast east and west of Santiago. Specifically in the Guantanamo Bay area of southern Cuba, Meinzer (1933) did a remarkable job of mapping what is now recognized as the Jaimanitas Formation, done without the aid of aerial photographs, and conducting his field studies on horseback in 1915.

Herein, we report results of new studies of the emergent coral reef record at Guantanamo Bay, with field mapping, stratigraphy, differential GPS elevation measurements, and ages of corals using uranium-series geochronology. These data, along with considerations of the Quaternary sea level record, allow determination of late Quaternary uplift rates. Specifically, we test the hypothesis that the southern coast of Cuba could be experiencing at least modest late Quaternary uplift due to a transpressional tectonic regime, using ages and elevations of an emergent coral reef terrace.

In addition, we wish to examine the coral reef record at Guantanamo Bay in order to test whether what is mapped as the Jaimanitas Formation in this part of Cuba dates to $120 \mathrm{ka}$, as in the Havana area. The last interglacial period, identified as marine isotope stage (MIS) 5.5 or 5e in the deep-sea, foraminiferal, oxygen- 
isotope record (Martinson et al., 1987), is of considerable interest as a possible analog for a future warmer Earth (Otto-Bliesner et al., 2006; Overpeck et al., 2006; Clark and Huybers, 2009; MurrayWallace and Woodroffe, 2014). There are, however, a number of interesting questions about this interglacial period, particularly with regard to its sea level history. Both modeling efforts (Kopp et al., 2009) and some field and geochronologic studies (Bloom et al., 1974; Esat et al., 1999; O'Leary et al., 2013; Schellmann and Radtke, 2004; Speed and Cheng, 2004; Stein et al., 1993; Thompson et al., 2011) indicate that there could have been at least two separate high stands of sea within the last interglacial period. In contrast, other modeling studies (Dutton and Lambeck, 2012; Lambeck et al., 2012) as well as field studies (Dutton et al., 2015; Muhs et al., 2002a, 2002b, 2011, 2012a, 2012b, 2014b; Stirling et al., 1998) do not indicate definitive evidence of more than a single high-sea stand during the last interglacial period.

Finally, there has been an increasing awareness of the importance of glacial isostatic adjustment (GIA) processes in understanding the Quaternary sea level record (e.g., Creveling et al., 2015; Lambeck et al., 2012; Milne and Mitrovica, 2008; Potter and Lambeck, 2003; Tamisiea and Mitrovica, 2011). These studies indicate that southern Cuba, due to its location relative to North American ice sheets, could have experienced a measureable, but modest departure from a purely eustatic sea level history during the late Quaternary, not as dramatic as a near-field locality such as Bermuda, but different from a far-field locality such as Barbados. Thus, if the late Quaternary uplift rate in the Guantanamo Bay area is low, as hypothesized, we should not expect to find reef terraces dating to the $\sim 100 \mathrm{ka}$ (MIS 5.3) or $\sim 80 \mathrm{ka}$ (MIS 5.1) sea stands.

\section{Methods}

Meinzer's (1933) map of the coral reef terraces around Guantanamo Bay was georeferenced successfully with modern satellite imagery and this was used as a mapping base. All delineations mapped as fossil coral reef deposits by Meinzer (1933) were checked in the field. Elevations of all localities studied were made using direct measurement by tape and hand level and/or by differential GPS measurements. GPS data were collected from at least four, and usually six to eight, satellites for at least $500 \mathrm{~s}$ to obtain consistent 3-D geometry. The data were post-processed using corrections against the closest active base stations. Differentially correcting the GPS elevations generally resulted in horizontal errors of $10 \mathrm{~cm}$ or less and vertical errors in the range of $20-80 \mathrm{~cm}$. Our measurements use the CARIB97 high-resolution geoid height model for the Caribbean Sea region (Smith and Small, 1999). Comparison of GPS-derived elevation measurements with taped or hand-leveled elevation measurements shows good agreement, within the limits of instrumental uncertainty.

Sections exposing the Jaimanitas Formation were described and measured at a variety of localities around Guantanamo Bay (Fig. 3) and well-preserved corals were sampled for U-series dating. Corals used in this study were cleaned mechanically, washed in distilled water and X-rayed for aragonite purity. All samples are at least 95\% aragonite and most are $98-100 \%$ aragonite (Table 1). After cleaning, sample preparation followed methods outlined by Ludwig et al. (1992) which are summarized briefly here. Cleaned corals were dissolved in $\mathrm{HNO}_{3}$, spiked with ${ }^{229} \mathrm{Th},{ }^{233} \mathrm{U}$, and ${ }^{236} \mathrm{U}$ and purified with ion-exchange methods. Purified $U$ and Th were loaded with colloidal graphite on separate Re filaments and isotopic abundances were determined by thermal ionization mass spectrometry (TIMS). The U-Th spike is calibrated against a solution of uranium ore from the Schwartzwalder Mine that has yielded concordant U/ $\mathrm{Pb}$ ages (Ludwig et al., 1985) and sample-to-sample agreement of ${ }^{234} \mathrm{U} /{ }^{238} \mathrm{U}$ and ${ }^{230} \mathrm{Th} /{ }^{238} \mathrm{U}$ (Ludwig and Paces, 2002). In addition, an in-house, carefully homogenized, aragonitic fossil coral of last interglacial age ( $120 \mathrm{ka})$ was used for run-to-run checks. Ages were calculated using a half-life of $75,584 \mathrm{yr}$ for ${ }^{230} \mathrm{Th}$ and a half-life of $245,620 \mathrm{yr}$ for ${ }^{234} \mathrm{U}$ (Cheng et al., 2013).

\section{Results}

\subsection{Coral reef distribution, stratigraphy, paleontology, and elevations}

Meinzer (1933) reported two coral reef terraces in the Guantanamo Bay area. The oldest terrace is described as occurring at $\sim 38 \mathrm{~m}$ above sea level and consists only of a small patch of limestone north of the modern runway on the leeward (western) side of the bay, covering an area of $\sim 0.32 \mathrm{~km}$ by $\sim 0.24 \mathrm{~km}$, centered at about $\mathrm{N} 19^{\circ} 54.6^{\prime}$ and $\mathrm{W} 75^{\circ} 13^{\prime}$. The elevation of this terrace, measured by us, is $\sim 39-40 \mathrm{~m}$ above sea level, and the reef consists of corals dominated by Diploria and Orbicella (the new genus Orbicella includes all species of the former Montastraea, with the exception of M. cavernosa; see Budd et al. (2012)). All corals we examined from this fossil reef are recrystallized and thus not collected for any analytical work.

A lower-elevation fossil reef rims much of Guantanamo Bay and was described by Meinzer (1933) as a terrace at $\sim 12 \mathrm{~m}$ above sea level. Our field studies conducted around Guantanamo Bay show that Meinzer's (1933) mapping of this lower terrace is very accurate and we made very few modifications to his delineations. The formation is widely distributed around the bay (Fig. 3) and much of the U.S. Naval base is built directly on the upper part of the emergent coral reef.

The limestone that forms this low terrace, the Jaimanitas Formation, varies spatially in its sedimentology and paleontology. We recognize both an exposed, outer-coast facies (Figs. 4 and 5) and a protected, inner bay (lagoonal) facies (Fig. 6). On the outer, exposed part of the coast (Kittery Beach to Glass Beach and Leeward Point to Chapman Beach; Fig. 3), the deposits consist of corals, rare mollusks, and occasional bedrock clasts within a matrix of carbonate sand. The deposits are up to $12 \mathrm{~m}$ thick, and the outer parts host Acropora palmata corals in growth position (Fig. 5a,c). Landward of the $A$. palmata reefs, growth-position occurrences of Orbicella nancyi, Montastraea cavernosa, and Siderastrea are common and are beautifully exposed at a number of localities (Fig. 5b,d). Orbicella nancyi is one of two locally extinct Pleistocene coral species that lived in the Caribbean region during past interglacial periods (Pandolfi, 2007; Pandolfi et al., 2001). This taxon was previously referred to as "organ pipe" Orbicella, based on its appearance in the field. The other locally extinct species, Pocillopora palmata, superficially looks somewhat like Orbicella nancyi from a distance in the field (see Fig. 5.1 of Pandolfi et al., 2001) and colonies can be of approximately the same size as 0 . nancyi. However, close examination of the Guantanamo corals with an organ-pipe structure reveals corallites of $\sim 2-2.5 \mathrm{~mm}$ diameter with $\sim 24$ septa, similar to Orbicella annularis. This indicates that the Cuban specimens are not $P$. palmata, which has smaller corallites $(\sim 1 \mathrm{~mm})$ and lacks septa (Budd et al., 1994).

Outer-coast localities in a few places are constructional reefs built on what appears to be a wave-cut platform, such as that seen at Girl Scout Beach (Fig. 4b). At Chapman Beach, what we also interpret as a wave-cut platform on Tertiary conglomerate hosts an upward-growing sequence of Acropora palmata corals in the lower 4-5 m, capped by smaller, growth-position colonies of Orbicella in the upper $\sim 2 \mathrm{~m}$, at an elevation of $14.8 \mathrm{~m}$ (Fig. 7). Elsewhere, marine deposits at the inner edges of the outer-coast facies reef deposits are as high as $14.3 \mathrm{~m}$ above sea level on the eastern side of the bay (Figs. 4a and 5a). 


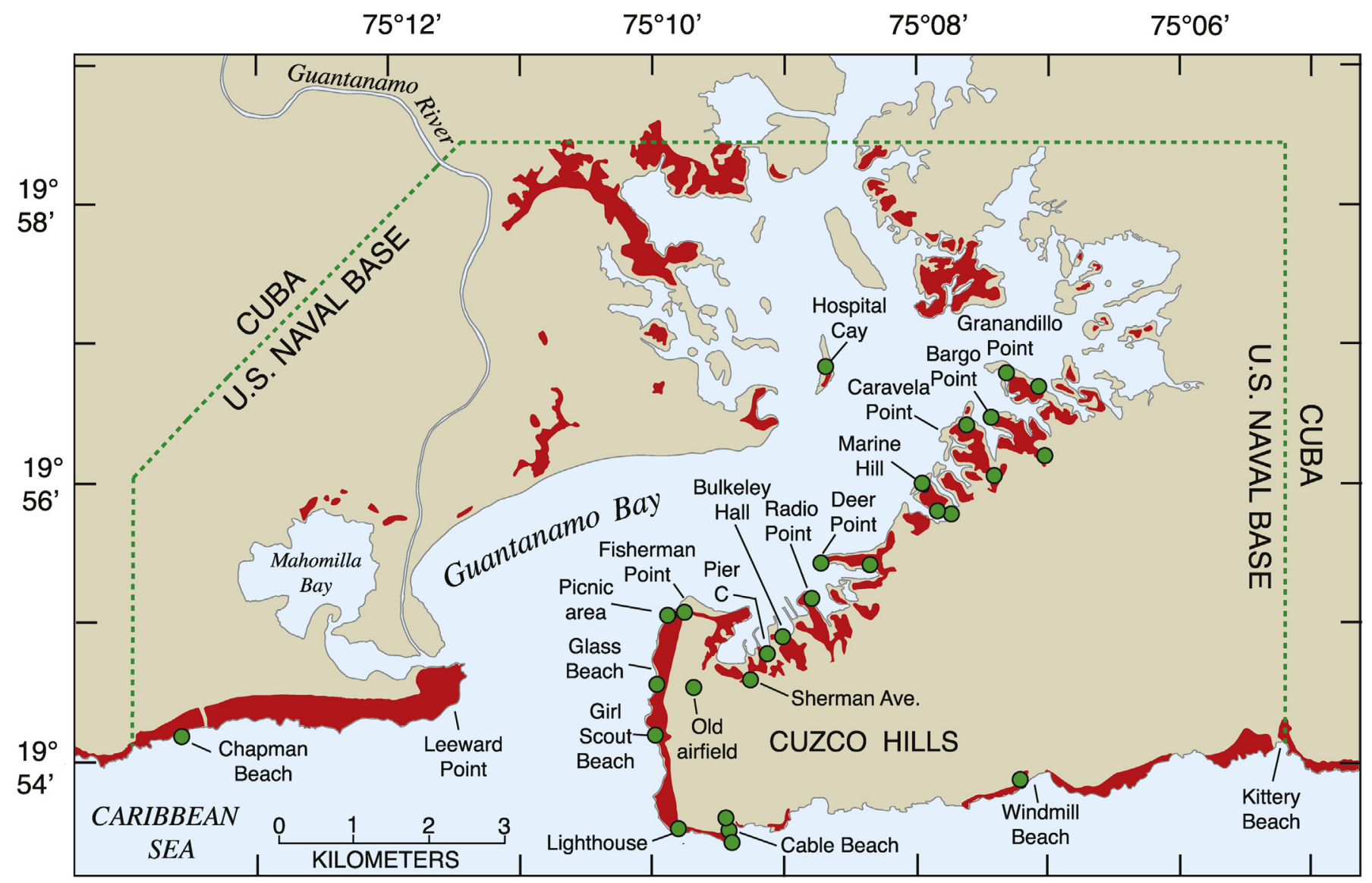

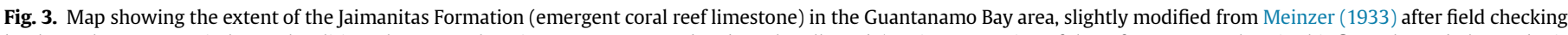

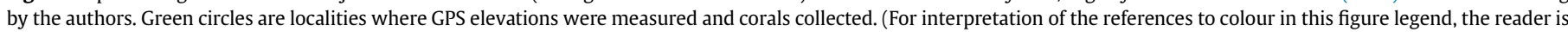
referred to the web version of this article.)

In the more protected, lagoonal parts of Guantanamo Bay, between Fisherman Point and Granandillo Point (Fig. 3), the Jaimanitas Formation is composed of constructional coral reefs, typically 7-10 m thick (Fig. 6). These deposits lack Acropora palmata, but are characterized by growth-position Orbicella nancyi colonies up to $2 \mathrm{~m}$ high, as well as smaller, growth-position colonies of Orbicella annularis, $M$. cavernosa, Siderastrea, Diploria, and Porites. The upper 2-3 $\mathrm{m}$ of the formation in such protected areas also contain, at several localities, abundant thickets of Acropora cervicornis, but all of these we examined are no longer in growth position. These dense accumulations of dominantly $A$. cervicornis branches appear to have accumulated from simple collapse, similar to what has been described by Speed and Cheng (2004) on Barbados. If so, then it is unlikely that the corals have experienced significant horizontal transport or reworking. Mollusks are also abundant in the lagoonal facies of the Jaimanitas Formation and include paired bivalves and a number of gastropods, described in detail by Portell et al. (2008).

As discussed earlier, a number of studies have proposed that there were at least two separate high stands of sea during the last interglacial period. A complex last-interglacial sea-level history of this sort has been proposed for both tectonically stable coasts, such as the Bahamas and Australia (Thompson et al., 2011; O'Leary et al., 2013) and tectonically rising coasts, such as New Guinea and Barbados (Bloom et al., 1974; Esat et al., 1999; Schellmann and Radtke, 2004; Stein et al., 1993). With the possibility that the low $(\sim 12 \mathrm{~m})$ terrace around Guantanamo Bay could date to the last interglacial period, we sought field evidence of a possible dual high-sea stand. Such evidence could be stratigraphic (two distinct reefs in vertical superposition, with a paleosol or karst-dominated surface between the two) or geomorphic (two or more distinct reef terraces, separated by a paleo-sea cliff). We found neither stratigraphic nor geomorphic evidence of more than one high-sea stand around Guantanamo Bay. In all sections we examined, we found no paleosols or contacts with karst features that could indicate subaerial exposure. At exposures of both protected, lagoonal reef facies and exposed, outer-coast reef facies, we found coral heads in growth position throughout all or most of the vertical extent of the sections exposed, indicating consistent upward reef growth during a single high-sea stand.

For exposed, outer-coast localities, the best estimate of relative paleo-sea level is defined by the elevation of the highest landward position of marine deposits lying above the wave-cut platform. At Windmill Beach, Cable Beach, the Lighthouse, and Fisherman Point, there is evidence of a wave-cut bench landward of the constructional reef, overlain by reworked and broken corals (Fig. $4 \mathrm{~b}$ and c). If this interpretation is correct, then these innermost elevations mark maximum shoreline positions of erosional marine terraces. In California (cf. Muhs et al., 2012b, 2014b), the junction of the wavecut platform and the backing sea cliff is called the shoreline angle and provides a close approximation of paleo-sea level. In the Guantanamo Bay area, our elevation measurements of the inner edges of outer-coast terrace deposits are likely maximum estimates of paleo-sea level, because the actual shoreline angles are not exposed. Elevations of the most landward marine deposits at these inner edges are as high as $14.3 \mathrm{~m}$ (Figs. 4a and $5 \mathrm{a}$ ). In contrast, the protected, lagoonal facies deposits exposed between Pier $\mathrm{C}$ and 
Table 1

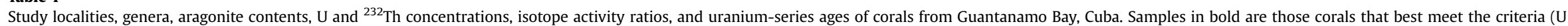
concentrations within range of modern corals, low ${ }^{232} \mathrm{Th}$ concentrations, and initial ${ }^{234} \mathrm{U} /{ }^{238} \mathrm{U}$ values close to the range for modern seawater) for closed-system histories and have the most reliable ages.

\begin{tabular}{|c|c|c|c|c|c|c|c|c|c|c|c|c|c|c|c|c|}
\hline Sample & Genus or species & $\begin{array}{l}\text { Arag- } \\
\text { onite (\%) }\end{array}$ & $\begin{array}{l}\text { Growth } \\
\text { position? }\end{array}$ & $\begin{array}{l}\text { Depth } \\
(\mathrm{m})^{\mathrm{a}}\end{array}$ & $\begin{array}{l}\mathrm{U} \\
\mathrm{ppm}\end{array}$ & \pm & $\begin{array}{l}{ }^{232} \mathrm{Th} \\
\mathrm{ppm}\end{array}$ & ${ }^{230} \mathrm{Th} /{ }^{232} \mathrm{Th}$ & $\begin{array}{l}{ }^{234} \mathrm{U} / /^{238} \mathrm{U} \\
\mathrm{AR}^{\mathrm{b}}\end{array}$ & \pm & $\begin{array}{l}{ }^{230} \mathrm{Th} /{ }^{238} \mathrm{U} \\
\mathrm{AR}\end{array}$ & \pm & $\begin{array}{l}{ }^{230} \mathrm{Th} /{ }^{238} \mathrm{U} \\
\text { Age }(\mathrm{ka})^{\mathrm{c}}\end{array}$ & \pm & $\begin{array}{l}{ }^{234} \mathrm{U}^{238} \mathrm{U} \\
\text { initial } \mathrm{AR}^{\mathrm{d}}\end{array}$ & \pm \\
\hline \multicolumn{17}{|c|}{ WINDMILL BEACH, modern corals from supratidal beach deposits: $\mathrm{N}^{19.89892^{\circ}, \mathrm{W}^{\prime} 5.11832^{\circ}}$} \\
\hline Cuba 16-1 & Orbicella annularis & 100 & No & NA & 2.30 & 0.11 & 0.0010 & 195 & 1.1507 & 0.0015 & 0.0285 & 0.0006 & 2.73 & 0.06 & 1.1519 & 0.0015 \\
\hline Cuba $16-2$ & Orbicella annularis & 100 & No & NA & 2.32 & 0.11 & 0.0006 & 140 & 1.1451 & 0.0021 & 0.0116 & 0.0015 & 1.11 & 0.15 & 1.1456 & 0.0021 \\
\hline Cuba $16-3$ & Orbicella annularis & 100 & No & NA & 2.75 & 0.11 & 0.0001 & 274 & 1.1515 & 0.0015 & 0.0038 & 0.0007 & 0.36 & 0.06 & 1.1516 & 0.0015 \\
\hline Cuba $16-4$ & Orbicella annularis & 100 & No & NA & 2.62 & 0.11 & 0.0002 & 339 & 1.1504 & 0.0017 & 0.0106 & 0.0010 & 1.01 & 0.09 & 1.1508 & 0.0017 \\
\hline Cuba $16-5$ & Orbicella annularis & 99 & No & NA & 3.02 & 0.11 & 0.0023 & 3190 & 1.1217 & 0.0017 & 0.8007 & 0.0026 & 131.7 & 0.90 & 1.1765 & 0.0023 \\
\hline Cuba $16-6$ & Montastraea cavernosa & 100 & No & NA & 2.50 & 0.11 & 0.0026 & 28 & 1.1475 & 0.0017 & 0.0093 & 0.0010 & 0.88 & 0.10 & 1.1479 & 0.0017 \\
\hline \multicolumn{17}{|c|}{ CABLE BEACH, modern corals from supratidal beach deposits: $\mathrm{N}^{19.89269^{\circ}, \mathrm{W}^{2} .15642^{\circ}}$} \\
\hline Cuba $30-\mathrm{A}$ & Siderastrea sp. & 100 & No & NA & 2.62 & 0.11 & 0.0000 & 0 & 1.1478 & 0.0016 & $\mathrm{x}$ & $\mathrm{x}$ & $\mathrm{x}$ & $\mathrm{x}$ & 1.1477 & 0.0016 \\
\hline Cuba $30-\mathrm{B}$ & Siderastrea sp. & 100 & No & NA & 2.35 & 0.12 & 0.0002 & 718 & 1.1434 & 0.0019 & 0.0224 & 0.0006 & 2.16 & 0.06 & 1.1438 & 0.0018 \\
\hline \multicolumn{17}{|c|}{ 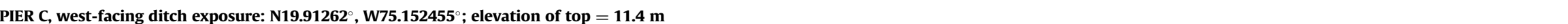 } \\
\hline Cuba 9-1B & Siderastrea sp. & 100 & Yes & 1.1 & 2.95 & 0.11 & 0.0001 & 87142 & 1.1108 & 0.0011 & 0.7702 & 0.0024 & 125.1 & 0.7 & 1.1577 & 0.0015 \\
\hline Cuba 9-1C & Siderastrea sp. & 100 & Yes & 1.3 & 3.03 & 0.12 & 0.0002 & 46561 & 1.1158 & 0.0017 & 0.7811 & 0.0018 & 127.1 & 0.7 & 1.1658 & 0.0022 \\
\hline Cuba 9-1D & Siderastrea sp. & 99 & Yes & 1.6 & 3.09 & 0.12 & 0.0001 & 48811 & 1.1190 & 0.0015 & 0.7805 & 0.0029 & 126.2 & 0.9 & 1.1699 & 0.0020 \\
\hline Cuba $9-1 \mathrm{E}$ & Siderastrea sp. & 100 & Yes & 1.7 & 3.02 & 0.11 & 0.0002 & 36197 & 1.1169 & 0.0013 & 0.7829 & 0.0018 & 127.4 & 0.6 & 1.1675 & 0.0018 \\
\hline Cuba 9-1F & Siderastrea sp. & $99-100$ & Yes & 1.9 & 2.87 & 0.12 & 0.0002 & 31808 & 1.1112 & 0.0012 & 0.7638 & 0.0024 & 123.1 & 0.8 & 1.1574 & 0.0016 \\
\hline Cuba $9-1 \mathrm{H}$ & Siderastrea sp. & 99 & Yes & 2.7 & 2.99 & 0.11 & 0.0006 & 12603 & 1.1215 & 0.0015 & 0.7879 & 0.0024 & 127.8 & 0.8 & 1.1743 & 0.0019 \\
\hline \multicolumn{17}{|c|}{ PIER C, east-facing road cut exposure: ${\mathrm{N} 19.91275^{\circ}, \mathrm{W} 75.15227^{\circ}}$ e elevation of top $=9.9 \mathrm{~m}$} \\
\hline Cuba 9-4a & Siderastrea sp. & 98 & Yes & 2.6 & 2.86 & 0.12 & 0.0021 & 3248 & 1.1141 & 0.0017 & 0.7844 & 0.0027 & 128.5 & 0.9 & 1.1641 & 0.0022 \\
\hline Cuba 9-4a rpt & Siderastrea sp. & 98 & Yes & 2.6 & 2.83 & 0.11 & 0.0012 & 5469 & 1.1163 & 0.0016 & 0.7868 & 0.0017 & 128.8 & 0.6 & 1.1672 & 0.0021 \\
\hline Cuba 9-4 & Siderastrea sp. & 99 & Yes & 2.6 & 3.03 & 0.11 & 0.0002 & 36057 & 1.1169 & 0.0017 & 0.7820 & 0.0021 & 127.2 & 0.7 & 1.1674 & 0.0022 \\
\hline Cuba 9-5 & Siderastrea sp. & $99-100$ & Yes & 3.2 & 2.99 & 0.11 & 0.0006 & 11267 & 1.1114 & 0.0019 & 0.7638 & 0.0022 & 123.1 & 0.8 & 1.1576 & 0.0025 \\
\hline Cuba 9-6 & Siderastrea sp. & 100 & Yes & 3.7 & 2.76 & 0.11 & 0.0001 & 82669 & 1.1104 & 0.0014 & 0.7809 & 0.0023 & 128.4 & 0.8 & 1.1586 & 0.0019 \\
\hline Cuba 9-7 & Siderastrea sp. & 100 & Yes & 4 & 2.69 & 0.11 & 0.0002 & 32097 & 1.1088 & 0.0018 & 0.7911 & 0.0026 & 132.0 & 0.9 & 1.1579 & 0.0024 \\
\hline Cuba 9-8 & Orbicella nancyi & 99 & Yes & 4.3 & 2.97 & 0.12 & 0.0029 & 2362 & 1.1138 & 0.0014 & 0.7563 & 0.0018 & 120.4 & 0.6 & 1.1598 & 0.0019 \\
\hline Cuba 9-9 & Orbicella nancyi & 98-99 & Yes & 4.7 & 2.39 & 0.11 & 0.0003 & 24224 & 1.1259 & 0.0015 & 0.8363 & 0.0028 & 142.0 & 1.0 & 1.1880 & 0.0020 \\
\hline Cuba 9-11 & Orbicella annularis & 100 & Yes & 5.7 & 2.24 & 0.11 & 0.0010 & 5893 & 1.1193 & 0.0013 & 0.8293 & 0.0033 & 141.6 & 1.2 & 1.1779 & 0.0019 \\
\hline Cuba $9-12$ & Orbicella annularis & 99 & No & 5.8 & 2.49 & 0.11 & 0.0001 & 56755 & 1.1161 & 0.0015 & 0.8059 & 0.0026 & 134.8 & 0.9 & 1.1698 & 0.0020 \\
\hline Cuba 9-13 & Montastraea cavernosa & $99-100$ & Yes & 6.2 & 2.71 & 0.11 & 0.0001 & 117481 & 1.1124 & 0.0014 & 0.8130 & 0.0020 & 138.1 & 0.8 & 1.1660 & 0.0020 \\
\hline Cuba 9-14 & Siderastrea sp. & 98-99 & Yes & 6.4 & 2.72 & 0.13 & 0.0095 & 672 & 1.1073 & 0.0017 & 0.7746 & 0.0024 & 127.2 & 0.8 & 1.1537 & 0.0022 \\
\hline Cuba 9-15 & Eusmilia fastigata & 99 & No? & 6.6 & 2.16 & 0.11 & 0.0013 & 3954 & 1.1120 & 0.0014 & 0.7735 & 0.0026 & 125.8 & 0.9 & 1.1598 & 0.0019 \\
\hline Cuba 9-16 & Siderastrea sp. & 100 & Yes & 6.8 & 2.57 & 0.11 & 0.0005 & 11694 & 1.1137 & 0.0014 & 0.7793 & 0.0019 & 127.1 & 0.7 & 1.1628 & 0.0019 \\
\hline Cuba 9-17 & Porites sp. & 99 & Yes & 7.2 & 2.74 & 0.11 & 0.0038 & 1732 & 1.1065 & 0.0020 & 0.7920 & 0.0021 & 132.9 & 0.9 & 1.1549 & 0.0027 \\
\hline \multicolumn{17}{|c|}{ PIER C, early (1998) exploratory samples } \\
\hline Cuba 1 & Siderastrea sideria & 100 & ? & $0-7$ & 2.61 & 0.12 & 0.0001 & 67332 & 1.1214 & 0.0018 & 0.7881 & 0.0026 & 127.9 & 0.9 & 1.1742 & 0.0024 \\
\hline Cuba 2 & Siderastrea sideria & 100 & ? & $0-7$ & 2.68 & 0.13 & 0.0004 & 15357 & 1.1243 & 0.0018 & 0.7878 & 0.0031 & 127.1 & 1.0 & 1.1780 & 0.0024 \\
\hline Cuba 3 & Solenastrea bournoni & 100 & ? & $0-7$ & 2.79 & 0.11 & 0.0000 & 197874 & 1.1153 & 0.0014 & 0.7751 & 0.0026 & 125.5 & 0.8 & 1.1643 & 0.0019 \\
\hline \multicolumn{17}{|c|}{ HOSPITAL CAY: N19.94774 ${ }^{\circ}$ W75.14455 $;$ elevation at top $=10.8 \mathrm{~m}$} \\
\hline Cuba 29-1 & Colpophyllia sp. & 100 & Yes & $\sim 4.5$ & 2.58 & 0.11 & 0.0001 & 63397 & 1.1086 & 0.0016 & 0.7487 & 0.0018 & 119.4 & 0.6 & 1.1521 & 0.0020 \\
\hline Cuba 29-2 & Orbicella nancyi & 98-99 & Yes & $\sim 4.5$ & 2.75 & 0.11 & 0.0025 & 2678 & 1.1195 & 0.0015 & 0.7952 & 0.0027 & 130.6 & 0.9 & 1.1727 & 0.0020 \\
\hline Cuba $29-3$ & Siderastrea sp. & $99-100$ & Yes & $\sim 4.5$ & 2.98 & 0.12 & 0.0003 & 21171 & 1.1084 & 0.0017 & 0.7795 & 0.0026 & 128.5 & 0.9 & 1.1558 & 0.0022 \\
\hline Cuba $29-4$ & Colpophyllia sp. & $98-99$ & Yes & $\sim 4.5$ & 2.56 & 0.11 & 0.0001 & 65619 & 1.1173 & 0.0017 & 0.7882 & 0.0019 & 128.9 & 0.7 & 1.1688 & 0.0022 \\
\hline \multicolumn{17}{|c|}{ 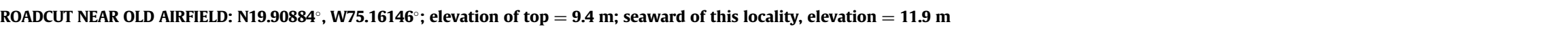 } \\
\hline Cuba $13-\mathrm{A}$ & Acropora cervicornis & 100 & No & & 2.55 & 0.12 & 0.0003 & 17787 & 1.1086 & 0.0017 & 0.7819 & 0.0028 & 129.2 & 1.0 & 1.1563 & 0.0022 \\
\hline
\end{tabular}

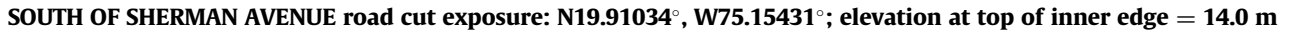




\begin{tabular}{|c|c|c|c|c|c|c|c|c|c|c|c|c|c|c|c|c|}
\hline Sample & Genus or species & $\begin{array}{l}\text { Arag- } \\
\text { onite (\%) }\end{array}$ & $\begin{array}{l}\text { Growth } \\
\text { position? }\end{array}$ & $\begin{array}{l}\text { Depth } \\
(\mathrm{m})^{\mathrm{a}}\end{array}$ & $\begin{array}{l}\mathrm{U} \\
\mathrm{ppm}\end{array}$ & \pm & $\begin{array}{l}{ }^{232} \mathrm{Th} \\
\mathrm{ppm}\end{array}$ & ${ }^{230} \mathrm{Th} /{ }^{232} \mathrm{Th}$ & $\begin{array}{l}{ }^{234} U /^{238} \mathrm{U} \\
\mathrm{AR}^{\mathrm{b}}\end{array}$ & \pm & $\begin{array}{l}{ }_{\text {AR }}^{230} \mathrm{Th} /{ }^{238} \mathrm{U} \\
\end{array}$ & \pm & $\begin{array}{l}{ }^{230} \mathrm{Th} /{ }^{238} \mathrm{U} \\
\text { Age }(\mathrm{ka})^{\mathrm{c}}\end{array}$ & \pm & $\begin{array}{l}{ }^{234} U / /^{238} U \\
\text { initial } A^{d}\end{array}$ & \pm \\
\hline Cuba $14-\mathrm{A}$ & Siderastrea sp. & 98-99 & Yes & $\sim 1.5$ & 3.65 & 0.12 & 0.0047 & 1898 & 1.1111 & 0.0014 & 0.8070 & 0.0023 & 136.5 & 0.9 & 1.1633 & 0.0020 \\
\hline Cuba 14-B & Siderastrea sp. & $98-99$ & Yes & $\sim 1.5$ & 3.33 & 0.12 & 0.0033 & 2361 & 1.1112 & 0.0018 & 0.7827 & 0.0024 & 128.8 & 0.8 & 1.1600 & 0.0024 \\
\hline \multicolumn{17}{|c|}{ 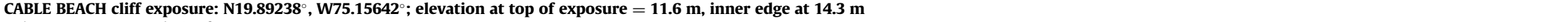 } \\
\hline Cuba 23-7 & Diploria cf. D. strigosa & $96-97$ & Yes & 3.6 & 2.63 & 0.11 & 0.0001 & 73058 & 1.1111 & 0.0017 & 0.7926 & 0.0020 & 131.9 & 0.8 & 1.1611 & 0.0022 \\
\hline Cuba 23-11 & Diploria sp. & 100 & Yes & 4.55 & 2.97 & 0.12 & 0.0001 & 71744 & 1.1152 & 0.0017 & 0.8017 & 0.0021 & 133.7 & 0.8 & 1.1679 & 0.0023 \\
\hline Cuba 23-6 & Diploria sp. & 100 & Yes & 4.9 & 2.88 & 0.13 & 0.0009 & 8171 & 1.1090 & 0.0021 & 0.7966 & 0.0027 & 133.7 & 1.0 & 1.1589 & 0.0028 \\
\hline Cuba 23-5 & Orbicella nancyi & 100 & Yes & 5.7 & 2.35 & 0.11 & 0.0001 & 68675 & 1.1301 & 0.0015 & 0.8676 & 0.0017 & 151.8 & 0.8 & 1.1996 & 0.0020 \\
\hline Cuba $23-5 \mathrm{~A}$ & Diploria sp. & 100 & Yes & 5.9 & 2.53 & 0.11 & 0.0003 & 23861 & 1.1017 & 0.0014 & 0.7858 & 0.0022 & 132.2 & 0.8 & 1.1477 & 0.0019 \\
\hline Cuba $23-4 \mathrm{~A}$ & Siderastrea sp. & 100 & Yes & 6.3 & 2.95 & 0.11 & 0.0000 & 171243 & 1.1218 & 0.0013 & 0.7994 & 0.0025 & 131.3 & 0.8 & 1.1764 & 0.0018 \\
\hline Cuba 23-3 & Orbicella nancyi & 99 & Yes & 7.35 & 2.32 & 0.11 & 0.0001 & 95381 & 1.1323 & 0.0016 & 0.8506 & 0.0026 & 145.1 & 1.0 & 1.1992 & 0.0022 \\
\hline Cuba $23-2$ & Diploria sp. & 100 & Yes & 7.35 & 3.08 & 0.11 & 0.0004 & 16446 & 1.1072 & 0.0016 & 0.7909 & 0.0021 & 132.3 & 0.8 & 1.1558 & 0.0021 \\
\hline Cuba $23-1$ & Diploria sp. & 100 & Yes & 7.8 & 2.48 & 0.11 & 0.0001 & 73156 & 1.1096 & 0.0017 & 0.7959 & 0.0021 & 133.3 & 0.8 & 1.1597 & 0.0022 \\
\hline \multicolumn{17}{|c|}{ CABLE BEACH, cliff exposure, $\sim 30 \mathrm{~m}$ to the north of main exposure: $\mathrm{N}^{19.89252^{\circ}, \mathrm{W}^{2} .15656^{\circ}}$} \\
\hline Cuba 23-10 & Diploria cf. D. strigosa & 100 & Yes & & 2.86 & 0.11 & 0.0001 & 122490 & 1.1098 & 0.0014 & 0.7729 & 0.0028 & 126.2 & 0.9 & 1.1567 & 0.0019 \\
\hline \multicolumn{17}{|c|}{ 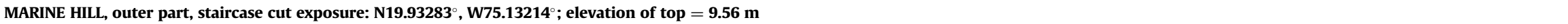 } \\
\hline Cuba 7-2 & Porites cf. P. asteroides & 99 & $?$ & 0.9 & 2.94 & 0.11 & 0.0018 & 3988 & 1.1170 & 0.0012 & 0.8014 & 0.0022 & 133.1 & 0.8 & 1.1704 & 0.0017 \\
\hline Cuba-7-3A & Siderastrea sp. & 99 & Yes & 0.8 & 2.90 & 0.11 & 0.0002 & 33759 & 1.1175 & 0.0016 & 0.7914 & 0.0028 & 129.9 & 0.9 & 1.1696 & 0.0021 \\
\hline Cuba 7-3B & Siderastrea sp. & 100 & Yes & 0.9 & 2.95 & 0.12 & 0.0002 & 32483 & 1.1195 & 0.0015 & 0.7760 & 0.0023 & 124.8 & 0.7 & 1.1700 & 0.0019 \\
\hline Cuba-7-3C & Siderastrea sp. & 99 & Yes & 1 & 2.86 & 0.12 & 0.0004 & 14982 & 1.1204 & 0.0017 & 0.7741 & 0.0022 & 124.0 & 0.7 & 1.1709 & 0.0022 \\
\hline Cuba7-3D & Orbicella sp. & 99 & Yes & 1.2 & 2.94 & 0.11 & 0.0001 & 106048 & 1.1387 & 0.0014 & 0.8403 & 0.0026 & 139.8 & 0.9 & 1.2057 & 0.0019 \\
\hline Cuba 7-4 & Siderastrea sp. & 100 & Yes & 5.2 & 3.69 & 0.13 & 0.0001 & 94913 & 1.1293 & 0.0014 & 0.6108 & 0.0019 & 83.3 & 0.4 & 1.1636 & 0.0016 \\
\hline Cuba 7-5 & Siderastrea sp. & 99 & Yes & 7 & 3.23 & 0.11 & 0.0003 & 22657 & 1.1067 & 0.0017 & 0.6478 & 0.0019 & 94.2 & 0.5 & 1.1392 & 0.0021 \\
\hline Cuba 7-6 & Siderastrea sp. & 99 & Yes & 7.2 & 3.27 & 0.12 & 0.0003 & 25150 & 1.1024 & 0.0034 & 0.6394 & 0.0019 & 92.9 & 0.7 & 1.1330 & 0.0043 \\
\hline Cuba-7-7 & Orbicella nancyi & 98-99 & Yes & 7.9 & 2.71 & 0.11 & 0.0003 & 21420 & 1.1165 & 0.0015 & 0.6752 & 0.0025 & 99.0 & 0.6 & 1.1540 & 0.0018 \\
\hline Cuba 7-8 & Diploria sp. & 99 & $?$ & 8.2 & 2.34 & 0.11 & 0.0001 & 49248 & 1.1117 & 0.0014 & 0.7292 & 0.0019 & 113.4 & 0.6 & 1.1538 & 0.0019 \\
\hline \multicolumn{17}{|c|}{ MARINE HILL, inner part, road cut exposure: $\mathrm{N}^{19.92992^{\circ}}{ }^{,} \mathrm{W}^{25.12940^{\circ}}$; elevation of top = $10.8 \mathrm{~m}$} \\
\hline Cuba 8-1 & Orbicella annularis & $99-100$ & Yes & 0.2 & 3.53 & 0.11 & 0.0001 & 66659 & 1.1260 & 0.0019 & 0.6736 & 0.0018 & 97.2 & 0.5 & 1.1658 & 0.0024 \\
\hline Cuba 8-2 & Siderastrea sp. & 99 & $?$ & 0.7 & 3.36 & 0.11 & 0.0002 & 29773 & 1.1148 & 0.0018 & 0.6668 & 0.0014 & 97.3 & 0.4 & 1.1511 & 0.0022 \\
\hline Cuba 8-3-a & Acropora cervicornis & 99 & No & 0.7 & 8.99 & 0.12 & 0.0012 & 11997 & 1.1091 & 0.0018 & 0.5210 & 0.0011 & 68.3 & 0.3 & 1.1323 & 0.0021 \\
\hline Cuba 8-3-a rpt & Acropora cervicornis & 99 & No & 0.7 & 7.63 & 0.12 & 0.0008 & 16952 & 1.1262 & 0.0018 & 0.6210 & 0.0015 & 85.7 & 0.4 & 1.1607 & 0.0022 \\
\hline Cuba 8-4 & Siderastrea sp. & 95 & Yes & 1.6 & 3.19 & 0.11 & 0.0010 & 7405 & 1.1122 & 0.0017 & 0.7620 & 0.0017 & 122.4 & 0.6 & 1.1584 & 0.0022 \\
\hline \multicolumn{17}{|c|}{ 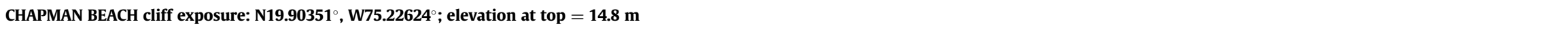 } \\
\hline Cuba-31-10 & Orbicella sp. & 98 & Yes & 0.7 & 2.93 & 0.11 & 0.0001 & 95742 & 1.1356 & 0.0015 & 0.8741 & 0.0048 & 152.3 & 1.8 & 1.2085 & 0.0022 \\
\hline Cuba-31-11 & Orbicella sp. & $98-99$ & Yes & 1.6 & 3.34 & 0.11 & 0.0002 & 48644 & 1.1723 & 0.0016 & 0.9792 & 0.0031 & 180.7 & 1.5 & 1.2870 & 0.0024 \\
\hline Cuba 31-8 & Acropora palmata & 99 & Yes & 5.1 & 4.56 & 0.11 & 0.0006 & 15204 & 1.1263 & 0.0017 & 0.6910 & 0.0020 & 101.2 & 0.5 & 1.1680 & 0.0021 \\
\hline Cuba-31-6 & Acropora palmata & $98-99$ & Yes & 5.5 & 3.77 & 0.11 & 0.0001 & 164592 & 1.1203 & 0.0015 & 0.7596 & 0.0020 & 119.9 & 0.6 & 1.1688 & 0.0019 \\
\hline Cuba-31-5 & Acropora palmata & 99 & Yes & 5.7 & 3.66 & 0.12 & 0.0038 & 2465 & 1.1380 & 0.0015 & 0.8453 & 0.0030 & 141.6 & 1.1 & 1.2058 & 0.0020 \\
\hline Cuba 31-4 & Acropora palmata & 100 & Yes & 5.9 & 3.70 & 0.11 & 0.0001 & 61934 & 1.1008 & 0.0017 & 0.7019 & 0.0020 & 108.3 & 0.6 & 1.1368 & 0.0021 \\
\hline Cuba 31-3 & Acropora palmata & 100 & Yes & 6.4 & 4.31 & 0.11 & 0.0002 & 35988 & 1.1084 & 0.0016 & 0.6588 & 0.0017 & 96.5 & 0.5 & 1.1423 & 0.0019 \\
\hline Cuba-31-2 & Acropora palmata & 99 & Yes & 6.8 & 3.93 & 0.11 & 0.0001 & 137563 & 1.1096 & 0.0013 & 0.7049 & 0.0015 & 107.4 & 0.5 & 1.1484 & 0.0017 \\
\hline Cuba 31-1 & Acropora palmata & 99 & Yes & 7.2 & 3.94 & 0.11 & 0.0001 & 76982 & 1.1099 & 0.0014 & 0.7698 & 0.0029 & 125.2 & 0.9 & 1.1564 & 0.0019 \\
\hline
\end{tabular}

a Depth from top of the exposure.

AR = activity ratio; errors are two-sigma.

c Calculated using half-lives of 75,584 yr for ${ }^{230} \mathrm{Th}$ and $245,620 \mathrm{yr}$ for ${ }^{234} \mathrm{U}$ (Cheng et al., 2013); errors are two-sigma.

d Back-calculated initial ${ }^{234} \mathrm{U} /{ }^{238} \mathrm{U}$ value using ${ }^{230} \mathrm{Th} / 238 \mathrm{U}$ age and measured ${ }^{234} \mathrm{U} /{ }^{238} \mathrm{U}$ value; errors are two-sigma. 

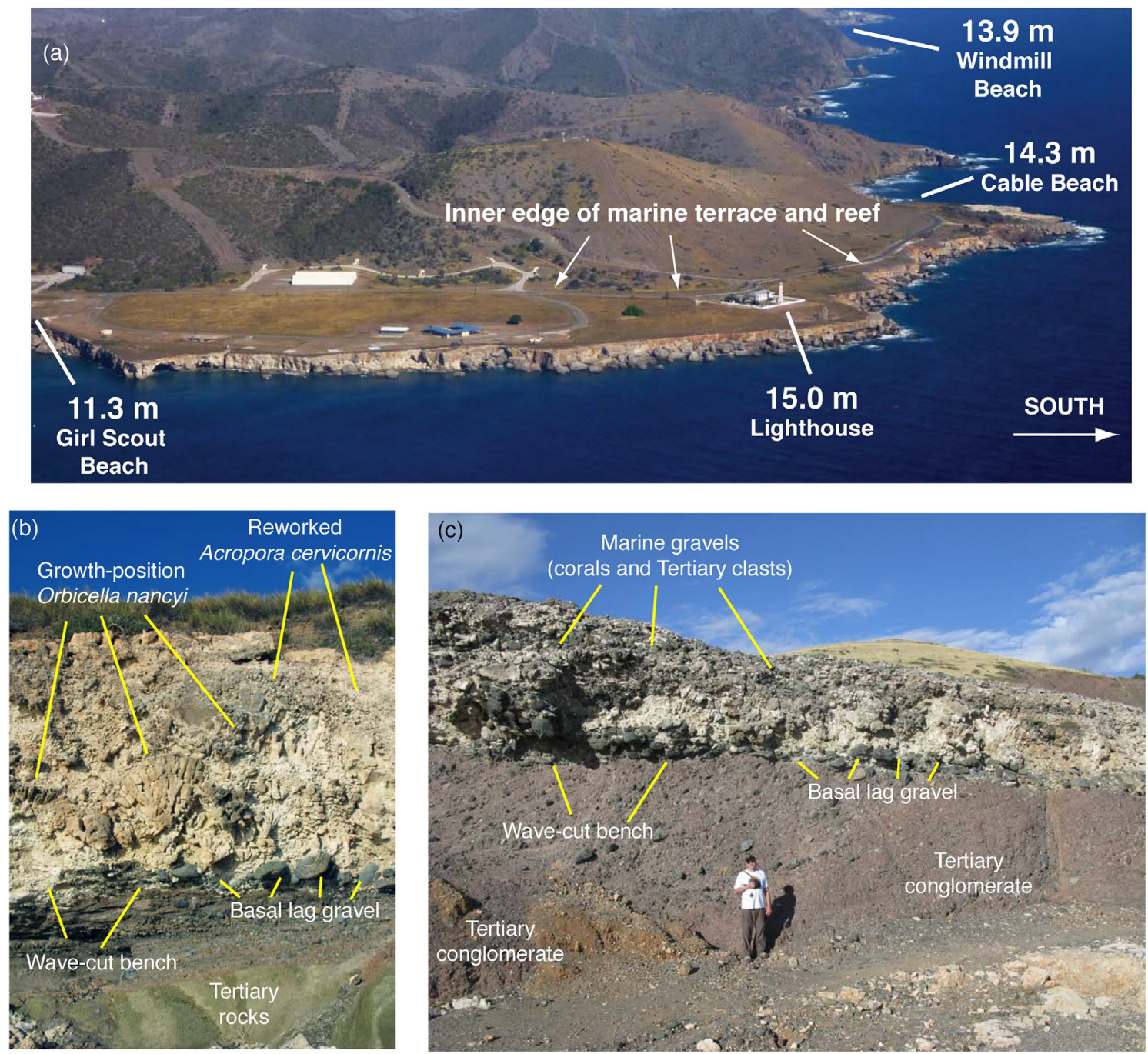

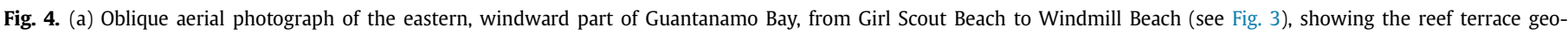

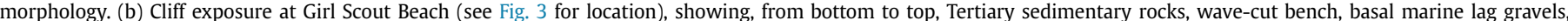

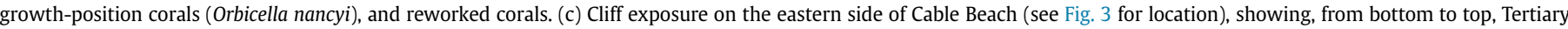
conglomerate, wave-cut bench, basal lag gravel, and marine gravels consisting of both coral fragments and clasts from Tertiary conglomerate; geologist in photo is $1.8 \mathrm{~m}$ tall.

Granandillo Point are composed almost entirely of growth-position corals and are therefore constructional landforms. Because corals must grow in some minimum depth of water, the highest elevations measured in the field are minimum estimates of paleo-sea level and require adjustment for coral habitat depth. Based on observations made by Shinn et al. (1989) in the nearby Florida Keys where the same coral taxa are found as in Cuba, minimum water depths for optimal growth of modern Orbicella annularis, M. cavernosa, Diploria, and Siderastrea siderea are $\sim 3 \mathrm{~m}$. Because Orbicella nancyi is extinct, there is no way to determine what correction might be appropriate for habitat depth for this species. In this study, we take a conservative approach and use the minimum water depth for optimal growth for the other genera ( $3 \mathrm{~m})$, as observed by Shinn et al. (1989). Following Muhs et al. (2011), we therefore add $3 \mathrm{~m}$ to our highest lagoonal facies elevations. Overall, results show that except for Chapman Beach, elevations of inner edges of outer-coast localities and habitat-depth-corrected elevations of protected, lagoonal localities are in good agreement, with apparent paleo-sea level elevations showing a narrow range between $\sim 13 \mathrm{~m}$ and $\sim 15 \mathrm{~m}$ (Fig. 8). Although the Chapman Beach locality is an outer, exposed reef locality (Fig. 3), there is no backing sea cliff that could define a shoreline angle. Nevertheless, the top of the reef complex at Chapman Beach is at $14.8 \mathrm{~m}$ above sea level and growth-position corals (Orbicella and Diploria) are found all the way to the top of the terrace. Thus, again assuming conservatively that these corals grew in water depths of at least $\sim 3 \mathrm{~m}$, this gives a corrected, apparent paleo-sea level elevation of $\sim 17.8 \mathrm{~m}$.

\subsection{Uranium-series dating}

We collected modern specimens of corals from supratidal beach drift at Windmill Beach and Cable Beach and fossil corals for uranium-series dating at Cable Beach, Chapman Beach, Hospital Cay, Marine Hill, Pier C, and two localities near the old airfield, south of Pier C (Fig. 3). At Cable Beach, Chapman Beach, Marine Hill, and Pier $\mathrm{C}$, corals were collected from the bottom to the top of each exposure, in part to test our field interpretation that the entire deposit represents a single high-sea stand. In assessing the integrity of U-series ages, we consider the following criteria, established during the early years of U-series geochronology by Broecker and Thurber (1965) and still valid today: (1) absence of recrystallization of primary aragonite to calcite, based on both examination of 

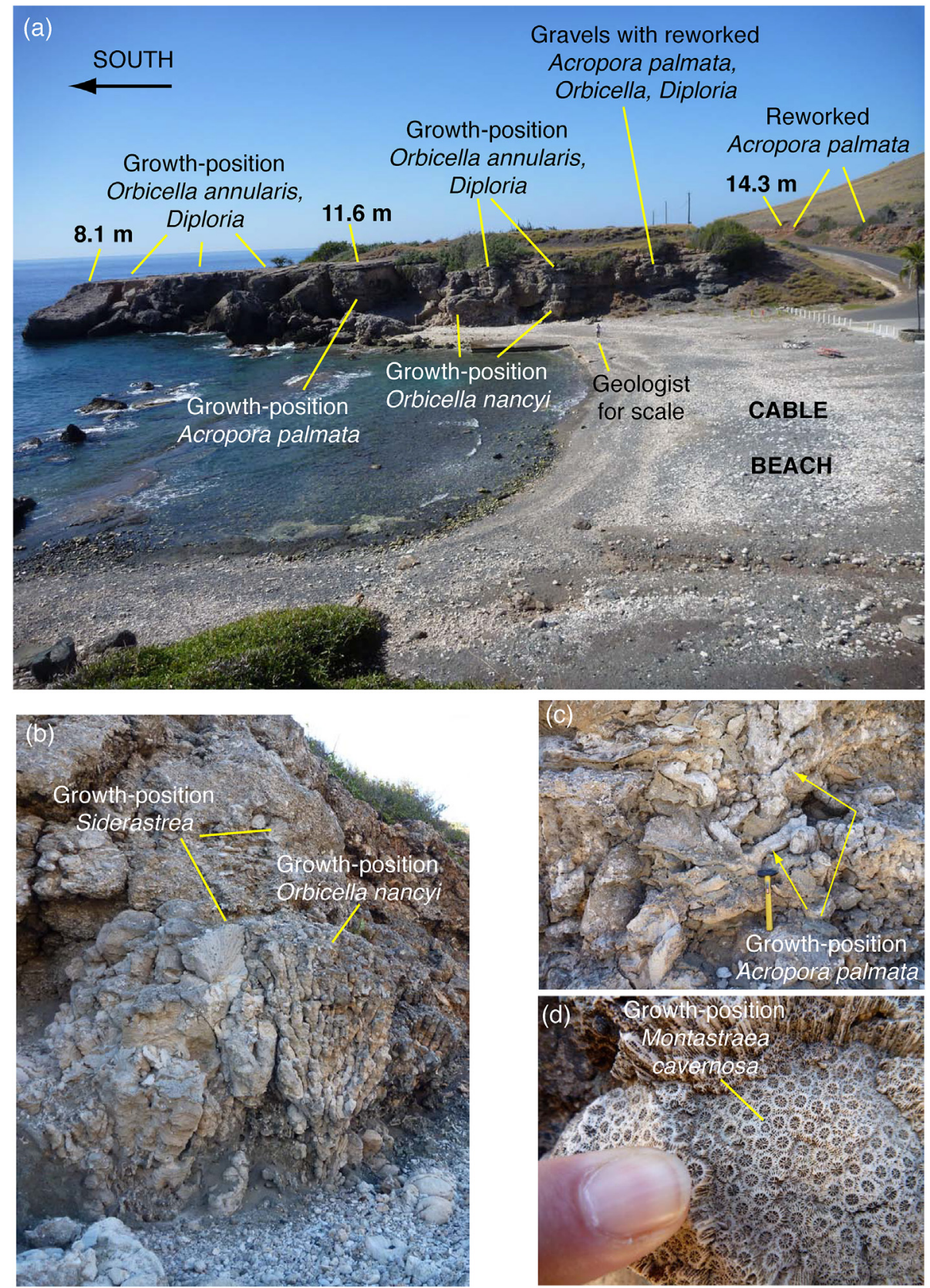

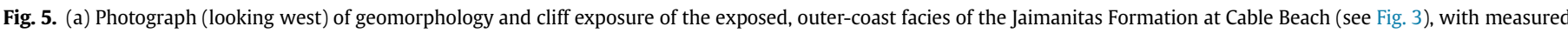

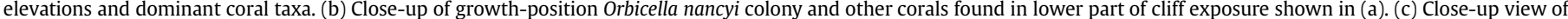

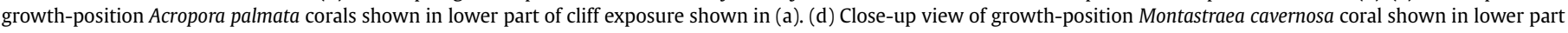
of cliff exposure shown in (a).

samples under magnification and X-ray diffraction analyses; (2) verification that ${ }^{230} \mathrm{Th}$ measured is due to in situ radioactive decay of parent ${ }^{234} \mathrm{U}$ and not from detrital silicate contaminants, confirmed by low concentrations of ${ }^{232} \mathrm{Th}$ and high values of ${ }^{230} \mathrm{Th} /{ }^{232} \mathrm{Th}$; (3) verification that bulk $\mathrm{U}$ concentrations are within the range of modern samples of the same species, indicating that there has been no gain or loss of $U$ since deposition; and (4) measured ${ }^{234} \mathrm{U} /{ }^{238} \mathrm{U}$ values that, when combined with apparent ${ }^{230} \mathrm{Th} /{ }^{234} \mathrm{U}$ ages, yield back-calculated initial ${ }^{234} \mathrm{U} /{ }^{238} \mathrm{U}$ values that fall within the range of modern seawater. Regarding criterion (1), one sample (Cuba 8-4) is 95\% aragonite and one other (Cuba 23-7) is $96-97 \%$ aragonite; all others are $98-100 \%$ aragonite and most are 99-100\% aragonite (Table 1). Apart from the modern beach- collected corals, criterion (2) is met for some but not all fossil corals. High ${ }^{232} \mathrm{Th}$ concentrations (and therefore low ${ }^{230} \mathrm{Th} /{ }^{232} \mathrm{Th}$ values) indicate significant inherited ${ }^{230} \mathrm{Th}$ from detrital silicate minerals and will bias samples to older apparent ages. The choice of what ${ }^{232} \mathrm{Th}$ concentration or which ${ }^{230} \mathrm{Th} /{ }^{232} \mathrm{Th}$ value to use as a threshold for determining whether there is significant contamination is typically chosen by the individual geochronologist. Thompson et al. (2011) considered corals with ${ }^{232}$ Th concentrations of greater than $0.0004 \mathrm{ppm}$ to have significant amounts of inherited ${ }^{230} \mathrm{Th}$. The fossil corals in the present study have ${ }^{232} \mathrm{Th}$ concentrations ranging from 0 to $0.0095 \mathrm{ppm}$ and ${ }^{230} \mathrm{Th} /{ }^{232} \mathrm{Th}$ values ranging from $\sim 670$ to $\sim 171,000$ (Table 1 ). Most corals with ${ }^{232} \mathrm{Th}$ concentrations of $0.0004 \mathrm{ppm}$ or less have ${ }^{230} \mathrm{Th} /{ }^{232} \mathrm{Th}$ 

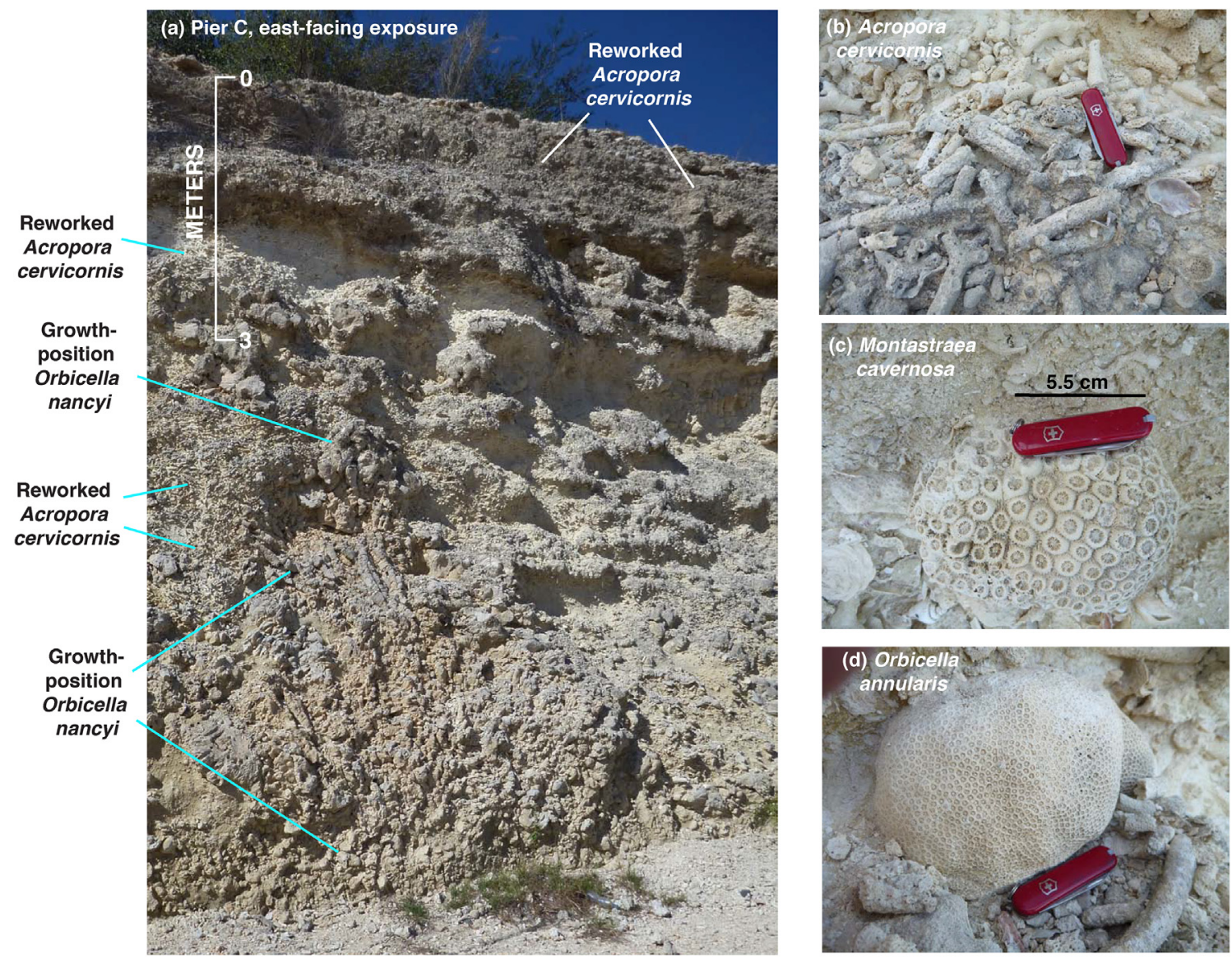

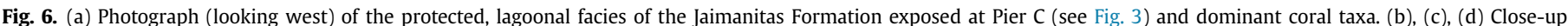
photographs of common coral taxa found in the exposure shown in (a) between depths of 3-4 $\mathrm{m}$. Knife in photos is $5.5 \mathrm{~cm}$ long.

values $>14,000$ (Cuba $8-3-\mathrm{a}\left[\mathrm{rpt}\right.$ ) and $31-8$ also have ${ }^{230} \mathrm{Th} /{ }^{232} \mathrm{Th}$ values $>14,000$, but have ${ }^{232} \mathrm{Th}$ values slightly $\left.>0.0004\right)$. The high ${ }^{230} \mathrm{Th} /{ }^{232} \mathrm{Th}$ values and low concentrations of ${ }^{232} \mathrm{Th}$ indicate that many, but not all of the corals contain little or no contaminating silicate mineral material, but we address this issue in more detail below. With some exceptions (e.g., Thompson et al., 2011), U-series geochronologists often overlook criterion (3), bulk U content, in their interpretations and regrettably some investigators do not even report such data. However, secondary additions of bulk U will bias samples to younger apparent ages and $U$ loss will bias samples to older apparent ages. Modern and Holocene specimens of Orbicella, Siderastrea, Diploria, and Porites have U concentrations of 2-3 ppm (Table 1; see also Cross and Cross, 1983; Chen et al., 1991; Ludwig et al., 1996; Muhs et al., 2011). Fossil specimens of Siderastrea with apparent closed-system histories sometimes have U contents slightly higher than 3 ppm (Martin et al., 1988; Gallup et al., 2002; Muhs et al., 2002a, 2014a; Speed and Cheng, 2004). In contrast, modern and Holocene species of Acropora (A. palmata and $A$. cervicornis) have $U$ concentrations of 3.0-3.8 ppm (Bard et al., 1990; Chen et al., 1991; Cross and Cross, 1983; Gallup et al., 1994; Hamelin et al., 1991; Thompson et al., 2011).

Finally, the best criterion for determining closed-system conditions during the post-emergence history of a fossil coral is concordance between ${ }^{230} \mathrm{Th} /{ }^{234} \mathrm{U}$ and ${ }^{231} \mathrm{~Pa} /{ }^{235} \mathrm{U}$ ages (Edwards et al., 1997, 2003). We did not determine ${ }^{231} \mathrm{~Pa} /{ }^{235} \mathrm{U}$ ages for our samples, nor do most U-series laboratories. However, another measure for closed-system history, criterion (4) given above, is a determination of whether the back-calculated initial ${ }^{234} U /{ }^{238} U$ value of a sample, based on its present measured ${ }^{234} U /{ }^{238} U$ value and the ${ }^{230} \mathrm{Th} /{ }^{234} \mathrm{U}$ age, is within the range of modern seawater. Modern seawater, commonly cited as having an "average" ${ }^{234} \mathrm{U} /{ }^{238} \mathrm{U}$ value of 1.149 , actually has a significant range of values, from 1.140 to 1.155 (Chen et al., 1986; Delanghe et al., 2002). Indeed, modern corals we collected on two beaches in the Guantanamo Bay area have ${ }^{234} \mathrm{U} /{ }^{238} \mathrm{U}$ values ranging from 1.143 to 1.152 (Table 1 ). Evaluation of back-calculated initial ${ }^{234} \mathrm{U} /{ }^{238} \mathrm{U}$ values has become, within the U-series geochronology community, the most commonly used measure for assessing closed-system history in Useries geochronology. Nevertheless, it is important to point out that this parameter has limitations. For example, Edwards et al. (1997) report that some corals with initial ${ }^{234} \mathrm{U} /{ }^{238} \mathrm{U}$ activity values as high as 1.166 show concordance between ${ }^{230} \mathrm{Th} /{ }^{234} \mathrm{U}$ and ${ }^{231} \mathrm{~Pa} /{ }^{235} \mathrm{U}$ ages. Conversely, Gallup et al. (2002) and Cutler et al. (2003) report a number of corals they analyzed that have "acceptable" backcalculated initial ${ }^{234} \mathrm{U} /{ }^{238} \mathrm{U}$ values, but do not show concordance between ${ }^{230} \mathrm{Th} /{ }^{234} \mathrm{U}$ and ${ }^{231} \mathrm{~Pa} /{ }^{235} \mathrm{U}$ ages. Gallup et al. (1994) point out that samples with elevated initial ${ }^{234} \mathrm{U} /{ }^{238} \mathrm{U}$ values from within the same reef terrace tend to yield older apparent ages and other studies have borne out this interpretation. On a ${ }^{230} \mathrm{Th} /{ }^{238} \mathrm{U}$ vs. ${ }^{234} U /{ }^{238} \mathrm{U}$ evolution diagram, such samples will plot above a theoretical isotope evolution pathway. Corals from both the present study (Fig. 9a) and those from the nearby Florida Keys (Fig. 9b), reported by Muhs et al. (2011), display the same tendency described by Gallup et al. (1994) in their study of Barbados corals. In the present study, we consider uncorrected ages calculated for fossil corals to be at least approximately accurate if they pass criteria 

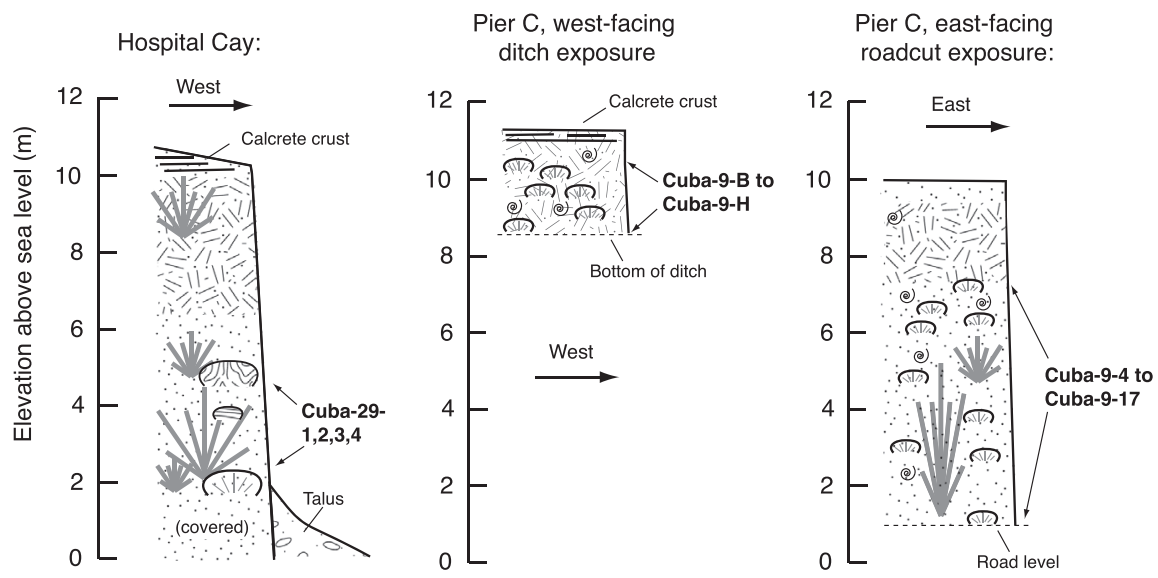

South of Sherman Avenue roadcut:
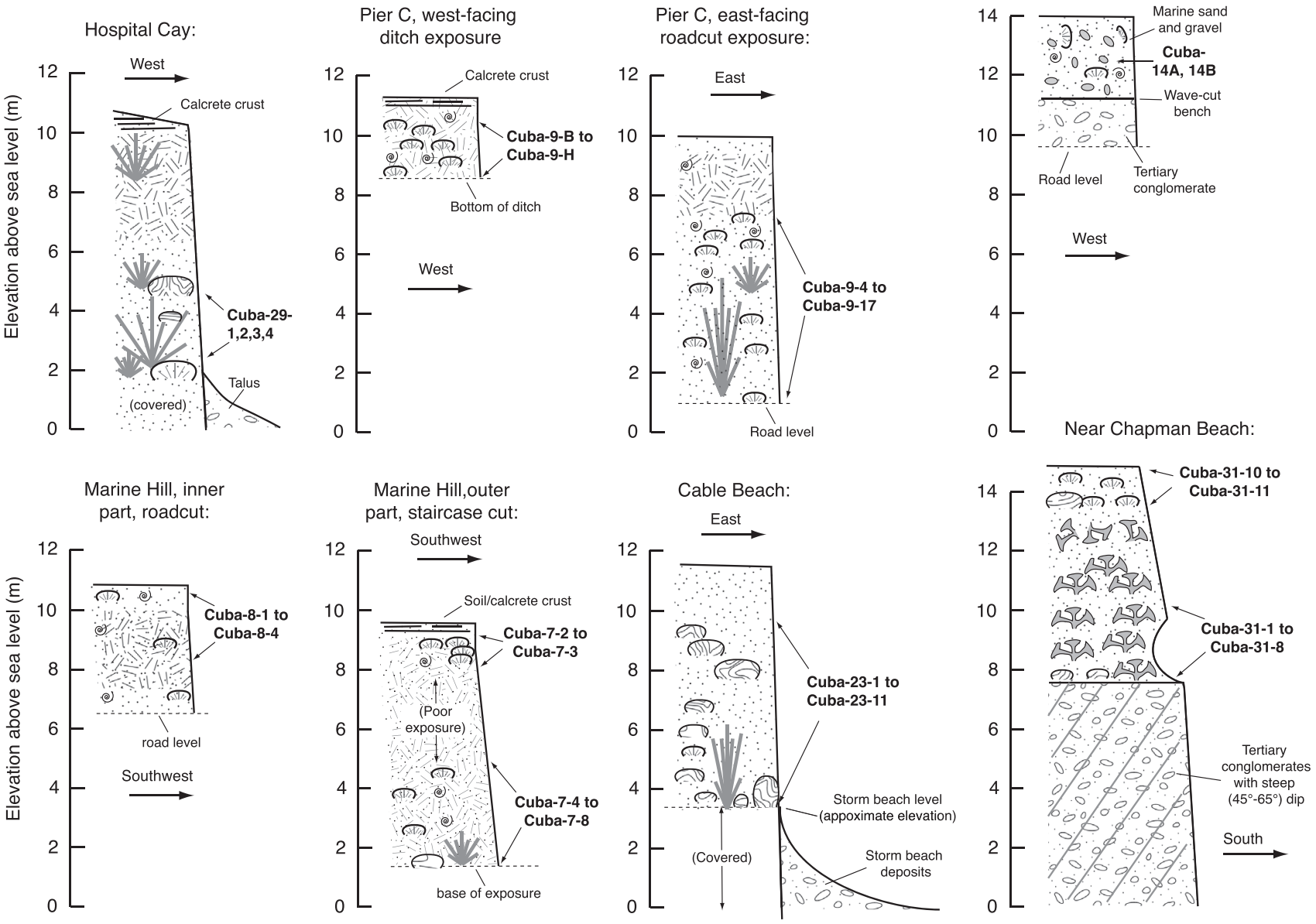

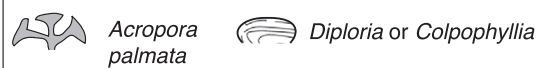

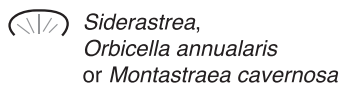

WV Orbicella nancyi

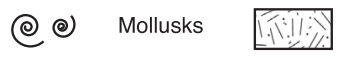

Acropora cervicornis,

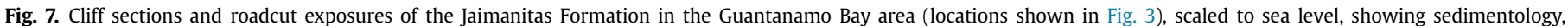
dominant coral taxa, and sample numbers (keyed to Table 1).

(1), (2), and (3), described above, and in addition have backcalculated initial ${ }^{234} \mathrm{U} /{ }^{238} \mathrm{U}$ activity values from 1.147 to 1.159 (following Stirling et al., 1998). This range of ${ }^{234} U /{ }^{238} U$ activity values is only slightly higher than the reported range of values in modern seawater but is consistent with the range in these values that Edwards et al. (1997) report for corals with concordant ${ }^{230} \mathrm{Th} /{ }^{234} \mathrm{U}$ and ${ }^{231} \mathrm{~Pa} /{ }^{235} \mathrm{U}$ ages.

Modern (dead) corals collected from supratidal deposits at Windmill Beach and Cable Beach (Fig. 3) have U concentrations similar to those reported elsewhere and measured ${ }^{234} \mathrm{U} /{ }^{238} \mathrm{U}$ values that fall into the range of modern seawater (Table 1). Orbicella annularis and Montastraea cavernosa from Windmill Beach, with one exception, have $U$ concentrations between 2.0 and $2.9 \mathrm{ppm}$, similar to what has been reported for living or modern-dead specimens of this genus elsewhere in the Caribbean and western Atlantic Ocean (Cross and Cross, 1983; Chen et al., 1991; Muhs et al., 2011). The one exception (Cuba 16-5) is an apparently reworked fossil derived from the nearby emergent marine deposits on the adjacent cliff, which gave an age of $131.7 \pm 0.9 \mathrm{ka}$. At Cable Beach, two modern Siderastrea fragments gave $U$ concentrations of 2.3-2.6 ppm, similar to what has been reported for modern specimens of this genus from Barbados and Bermuda (Cross and Cross,
1983; Ludwig et al., 1996). Overall, measured ${ }^{234} \mathrm{U} /{ }^{238} \mathrm{U}$ values in the modern corals range from 1.143 to 1.152 , within the range of what has been reported for modern seawater (Delanghe et al., 2002).

For fossil corals at Guantanamo Bay, the best results, considering all the criteria described above, come from the protected, lagoonal facies exposures at Pier C (Figs. 3, 6 and 7). All samples collected from this section yielded $U$ contents within the range of modern corals. Some samples have concentrations of ${ }^{232} \mathrm{Th}$ greater than $0.0004 \mathrm{ppm}$, indicating some amount of inherited ${ }^{230} \mathrm{Th}$, using the criterion of Thompson et al. (2011). These include Cuba 9-1H, 9-4a, $9-5,9-8,9-11,9-14,9-15,9-16$, and 9-17. The oldest part of the section is the east-facing roadcut exposure and the lowest coral exposed (Cuba 9-17, at a depth of $7.2 \mathrm{~m}$ from the top of the exposure), a Porites, has an age of $132.9 \pm 0.9 \mathrm{ka}$, with an initial ${ }^{234} \mathrm{U} /{ }^{238} \mathrm{U}$ value of 1.1549, indicating minimal bias to an older possible age. Continuing up-section, corals above this depth with initial ${ }^{234} \mathrm{U} /{ }^{238} \mathrm{U}$ values less than 1.159 range in age from $127.2 \pm 0.8 \mathrm{ka}$ (Cuba 9-14, at $6.4 \mathrm{~m}$ ), $132.0 \pm 0.9 \mathrm{ka}$ (Cuba 9-7, at $4.0 \mathrm{~m}$ ), $128.4 \pm 0.8$ ka (Cuba 9-6, at $3.7 \mathrm{~m}$ ), and $123.1 \pm 0.8 \mathrm{ka}$ (Cuba 9-5, at $3.2 \mathrm{~m}$ ). On the ditch exposure facing west, all samples except Cuba $9-1 \mathrm{H}$ are statigraphically above all the sampled corals on the east-facing 


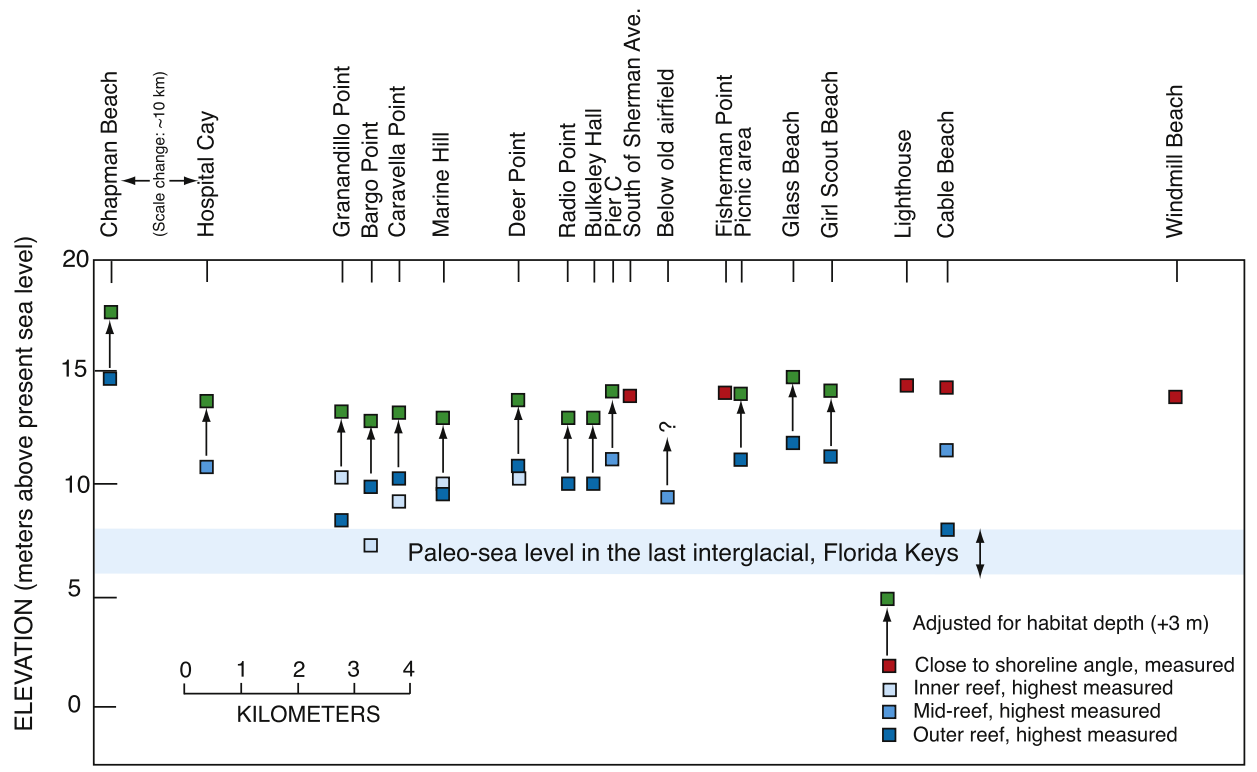

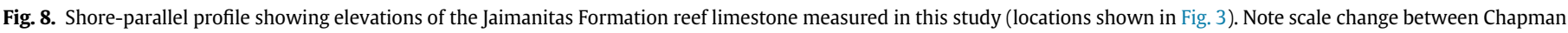

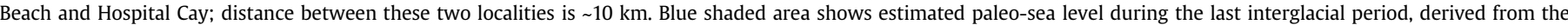

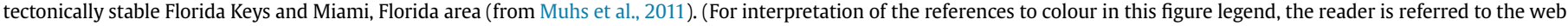
version of this article.)

exposure. The upper part of the west-facing ditch exposure has a Siderastrea at $1.9 \mathrm{~m}$ depth (Cuba 9-1F) with an age of $123.1 \pm 0.8 \mathrm{ka}$ and another Siderastrea at $1.1 \mathrm{~m}$ depth (Cuba 9-1B) with an age of $125.1 \pm 0.7 \mathrm{ka}$, both with initial ${ }^{234} \mathrm{U} /{ }^{238} \mathrm{U}$ values less than 1.159 . Corals at intermediate depths have similar apparent ages, but have slightly higher initial ${ }^{234} \mathrm{U} /{ }^{238} \mathrm{U}$ values. Taken at face value, all the corals in both exposures of Pier C fall into the range of ages for MIS 5.5 found on other coastlines, but do not have a clear stratigraphic integrity. Similar results were obtained from the corals collected between $\sim 5 \mathrm{~m}$ and $\sim 7 \mathrm{~m}$ depth from the protected, lagoonal facies exposure on Hospital Cay. Of the four corals sampled here, two (Cuba 29-3, 29-1) had initial ${ }^{234} \mathrm{U} /{ }^{238} \mathrm{U}$ values less than 1.159 and gave ages of $128.5 \pm 0.9 \mathrm{ka}$ and $119.4 \pm 0.6 \mathrm{ka}$, respectively. The other two corals have elevated initial ${ }^{234} \mathrm{U} /{ }^{238} \mathrm{U}$ values and are likely biased old by some amount, but still fall into the age range of MIS 5.5.

Of the exposed, outer-coast facies localities, the best results come from Cable Beach (Figs. 3-5). With one exception (Cuba 23-2, with a slightly higher $U$ content), all corals collected from this section yielded $U$ contents within the range of modern corals and have very high ${ }^{230} \mathrm{Th} /{ }^{232} \mathrm{Th}$ values, indicating no significant amounts of inherited ${ }^{230} \mathrm{Th}$. From this outcrop, three corals (Cuba $23-2,23-5 A$, and $23-6$ ) all have initial ${ }^{234} U /{ }^{238} U$ values less than 1.159 (Table 1; note, however, that Cuba 23-6 has a lower than optimal ${ }^{230} \mathrm{Th} /{ }^{232} \mathrm{Th}$ ). These corals have ages of $132.3 \pm 0.8 \mathrm{ka}$ (near the base of the exposure) and $132.2 \pm 0.8 \mathrm{ka}$ and $133.7 \pm 1.0 \mathrm{ka}$ 2-3 $\mathrm{m}$ above the base of the exposure. About $30 \mathrm{~m}$ inland (north) of the main exposure shown in Figs. 5b and 7, a growth-position Diploria (Cuba 23-10) was collected above a complex series of gravel layers and gave an age of $126.2 \pm 0.9 \mathrm{ka}$ with an initial ${ }^{234} \mathrm{U} /{ }^{238} \mathrm{U}$ value of 1.1567 , indicating minimal age bias. The remaining corals from Cable Beach have slightly elevated initial ${ }^{234} U{ }^{238} U$ values (Cuba $23-1,4 A, 7,11$ ) or more significantly elevated initial ${ }^{234} U /{ }^{238} U$ values (Cuba $23-3$ and Cuba $23-5$ ). With the exception of the latter two samples, all the corals from Cable Beach, as with those at Pier C and Hospital Cay, have ages that fall into the general age range of MIS 5.5.

In a roadcut exposure south of Sherman Avenue (Fig. 3), a bench is cut on Tertiary conglomerates and is overlain by $2.6 \mathrm{~m}$ of marine deposits. The bench has an elevation of $11.4 \mathrm{~m}$ and the top of the marine deposits has an elevation, at its most-landward exposure, of $14.0 \mathrm{~m}$. Within the marine deposits, clasts are composed of Tertiary rocks, transported coral fragments, and gastropods, including paired bivalves. However, we also found small coral heads, dominated by Siderastrea, apparently in growth position, on gravel clasts derived from Tertiary rocks. Two of these corals, Cuba 14-A and 14$B$, have slightly elevated $U$ contents $(3.3-3.6 \mathrm{ppm})$ and initial ${ }^{234} \mathrm{U} /{ }^{238} \mathrm{U}$ values (1.1633 and 1.1600 ), but gave apparent ages of $136.5 \pm 0.9$ and $128.8 \pm 0.8 \mathrm{ka}$, respectively. Less than a kilometer to the west, a roadcut exposure just east of the old airfield (Cuba 13-A) has a stratigraphy similar to that of Cuba-14, where a bench is cut on Tertiary conglomerates and is overlain by corals and mollusks, most of which are not in growth position. The top of the marine gravels has an elevation of $9.4 \mathrm{~m}$. An Acropora cervicornis coral was collected from these gravels, but gave a U content of only $2.55 \mathrm{ppm}$, indicating probable U loss.

Less success was achieved with attempts to date corals at the other sections that were visited, Marine Hill (inner part), Marine Hill (outer part), and Chapman Beach (Figs. 3 and 7). Both of the Marine Hill sections are protected, lagoonal facies exposures. In the outer of these two outcrops, the top of the reef is at an elevation of $9.6 \mathrm{~m}$, and $\sim 8 \mathrm{~m}$ of reef carbonate can be seen. The reef here consists mostly of broken Acropora cervicornis sticks, with growth-position Siderastrea and less-common Porites, Orbicella, and Diploria. The interval from $\sim 1.2 \mathrm{~m}$ down to $\sim 5 \mathrm{~m}$ is poorly exposed and no samples were taken in this zone. In the upper $1.2 \mathrm{~m}$, five corals (Cuba 7-2, 3A, 3B, 3C, and 3D) gave apparent ages of $\sim 140$ ka to 124 $\mathrm{ka}$, although all have high initial ${ }^{234} \mathrm{U} /{ }^{238} \mathrm{U}$ values and are likely biased old to one degree or another (Table 1). Nevertheless, these corals have high ${ }^{230} \mathrm{Th} /{ }^{232} \mathrm{Th}$ values and $\mathrm{U}$ contents that fall within the range (2-3 ppm) for modern specimens of these genera. At a depth of $5.2 \mathrm{~m}$ and below, all five corals sampled have significantly younger ages ( $\sim 113 \mathrm{ka}$ to $\sim 83 \mathrm{ka}$ ), clearly at variance with the stratigraphy, even though all corals but one are in growth position. Three of these (Cuba 7-4, 5, 6) are Siderastrea specimens that have $U$ contents of 3.2-3.7 ppm. Although, as noted earlier, this genus can 

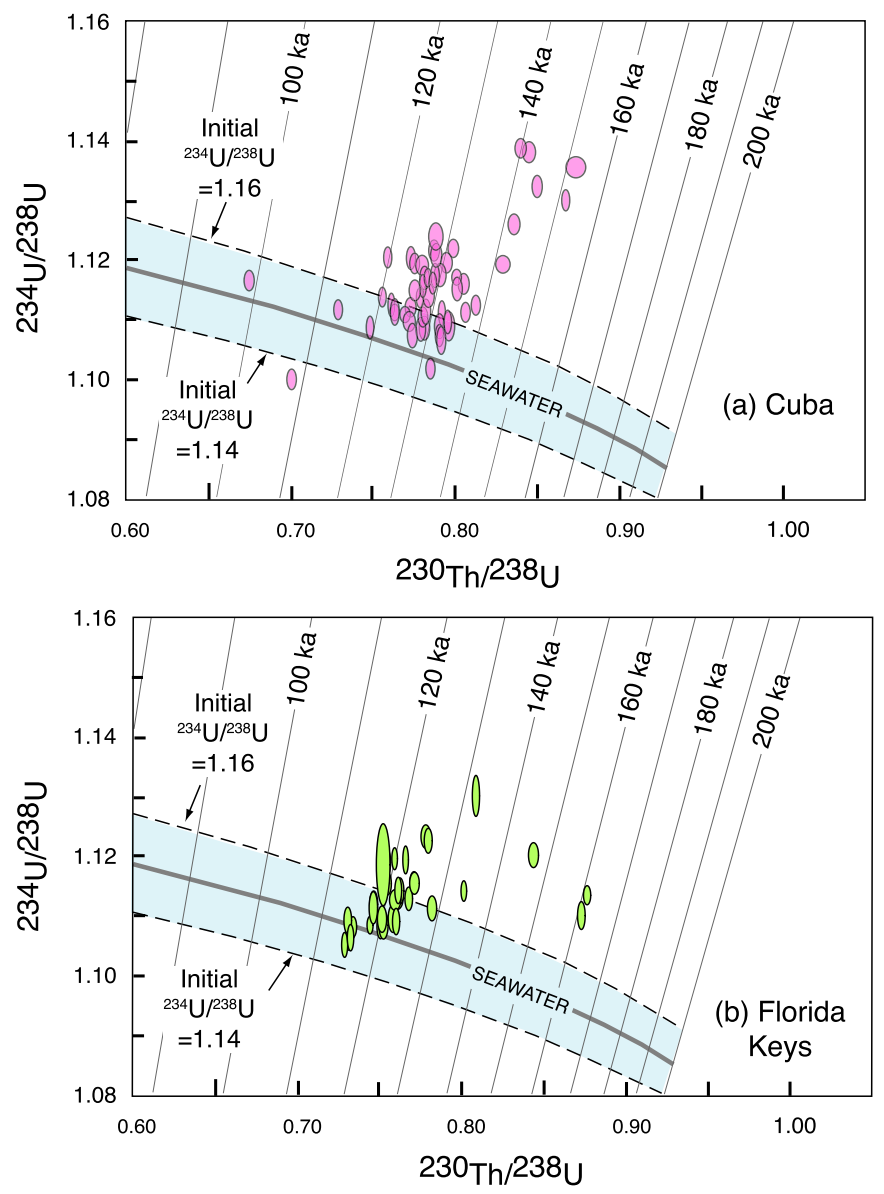

Fig. 9. Isotopic evolution diagrams (drawn using software in Ludwig, 2001) of (a) corals from the Jaimanitas Formation at Guantanamo Bay (this study) and (b) corals from the Key Largo Limestone of the Florida Keys (from Muhs et al., 2011). Ellipses show 2-sigma uncertainties in isotopic activity ratios. Bold solid line shows theoretical isotopic evolution pathway for a coral with an initial ${ }^{234} U /{ }^{238} \mathrm{U}$ activity value of 1.15 (modern mean seawater value) and a closed-system history; dashed lines show similar pathways for corals with initial ${ }^{234} \mathrm{U} /{ }^{238} \mathrm{U}$ values of 1.16 and 1.14 , values that bound the range of variability of modern seawater. Not included in figure are samples that have evidence of bulk U loss or gain (see Table 1).

sometimes have $U$ contents this high, we note that neither the fossil Siderastrea higher in this section nor the modern Siderastrea at Cable Beach have $U$ contents as high as these lower in the section. Hence, we suspect that these samples have acquired secondary addition of bulk $U$ sometime after emergence and such additions would explain the younger apparent ages if the corals were of lastinterglacial age. Furthermore, two of these corals (Cuba 7-5 and 76 ) have initial ${ }^{234} U /{ }^{238} U$ values that are lower than what is found in modern seawater. Both Cuba 7-7 and 7-8, found below the problematic Siderastrea specimens, have U contents that fall within the range of values reported for modern Orbicella and Diploria. Nevertheless, because these two corals are physically close to the problematic samples, we also consider Cuba 7-7 and 7-8 to be suspect and do not include them in our interpretations.

The roadcut exposure in the inner part of the reef exposed on Marine Hill also shows problems with likely U additions. Cuba 8-1, $8-2$, and 8-4 are Orbicella and Siderastrea that have $U$ contents above $3 \mathrm{ppm}$, higher than their modern equivalents that we analyzed (Table 1). Although Cuba 8-4 gives an age that is consistent with those for corals at Pier C, Hospital Cay, Cable Beach, and the other localities, both Cuba 8-1 and 8-2 give younger-thanexpected ages, again suggesting secondary $U$ additions. Cuba 8-
3A, an Acropora cervicornis specimen from this section, shows the most obvious example of secondary $U$ addition, with a $U$ content of $\sim 9 \mathrm{ppm}$ and a much younger-than-expected age. An analysis from a different part of this coral gave different results, but also yielded a high $U$ content $(\sim 7 \mathrm{ppm})$ and again a younger-than-expected age. Different initial ${ }^{234} \mathrm{U} /{ }^{238} \mathrm{U}$ values (one lower than modern seawater) as well as different measured ${ }^{230} \mathrm{Th} /{ }^{238} \mathrm{U}$ values in these two subsamples indicate that the secondary $U$ addition process in this sample is complex. We therefore reject all apparent ages from this outcrop.

Finally, poor results were also obtained from most of the corals sampled in the exposed, outer-reef facies cliff section at Chapman Beach. $U$ contents above $4 \mathrm{ppm}$, higher than in modern corals, were measured in Acropora palmata specimens Cuba 31-3 and 31-8. Apparent ages of these corals are significantly younger than those from the other parts of Guantanamo Bay. Cuba 31-4, also an Acropora palmata specimen, gave a $U$ content of $3.7 \mathrm{ppm}$, within the range of modern corals of this genus (Cross and Cross, 1983), but this sample also gave an initial ${ }^{234} U /{ }^{238} U$ value below that of modern seawater. Cuba 31-11, an Orbicella, gave a U content of $3.34 \mathrm{ppm}$, which is too high for this genus (Table 1). Two of the other corals sampled at this section, Cuba 31-5 and 31-10 (as well as Cuba 31-11), have initial ${ }^{234} U /{ }^{238} U$ values greater than 1.20 , well above the range of modern seawater. Only two samples (Cuba 316 at $5.5 \mathrm{~m}$ depth and Cuba 31-1, at $7.2 \mathrm{~m}$ depth), both Acropora palmata colonies in growth position, yielded acceptable $U$ contents, high ${ }^{230} \mathrm{Th} /{ }^{232} \mathrm{Th}$ values, and initial ${ }^{234} \mathrm{U} /{ }^{238} \mathrm{U}$ values that, while higher than modern seawater, are not excessively high. These two corals gave apparent ages of $\sim 120 \mathrm{ka}$ and $\sim 125 \mathrm{ka}$. Because of the variable and complex evidence for open-system conditions at Chapman Beach, we reject all other apparent ages of corals from this section.

\subsection{Open-system uranium-series ages}

As discussed earlier, Gallup et al. (1994) pointed out that corals with elevated initial ${ }^{234} \mathrm{U} /{ }^{238} \mathrm{U}$ values from within the same reef terrace tend to yield older apparent ages and other studies have borne out this interpretation. Thompson et al. (2003), following on the observations of Gallup et al. (1994), devised a scheme for correcting apparent older-aged corals that have elevated initial ${ }^{234} \mathrm{U} /{ }^{238} \mathrm{U}$ activity values. This method, applied to corals on Barbados (Muhs and Simmons, 2017; Thompson and Goldstein, 2005), the Bahamas (Thompson et al., 2011), and Australia (O'Leary et al., 2013) appears to yield geologically reasonable "corrected" open-system ages. It is likely that the variables affecting open-system behavior in corals include lithology, hydrogeology, climate, and sedimentology, and will vary from region to region. Thus, the U-series geochronology community has not yet reached a consensus on whether a correction scheme such as that of Thompson et al. (2003) has universal validity. Nevertheless, here we present corrected open-system ages, using the method of Thompson et al. (2003), in order to show alternative interpretations of the coral ages. We limited our calculations to those samples that do not have evidence of bulk $U$ additions or loss, do not have initial ${ }^{234} \mathrm{U} /{ }^{238} \mathrm{U}$ activity values in excess of 1.20 , or have initial ${ }^{234} \mathrm{U} /{ }^{238} \mathrm{U}$ activity values below the range of modern seawater. We also note which samples have, by the criterion of Thompson et al. (2011), ${ }^{232} \mathrm{Th}$ concentrations that are above the threshold value ( $>0.0004 \mathrm{ppm}$ ) used by these investigators, indicating a potentially significant amount of inherited ${ }^{230} \mathrm{Th}$.

Applying the Thompson et al. (2003) correction method to corals from Guantanamo Bay results in corrections (to younger ages) ranging from as little as a couple hundred years for Cuba 23$5 \mathrm{~A}$ to as much as $\sim 17$ ka for Cuba 9-9 (Table 2). Open-system ages 
Table 2

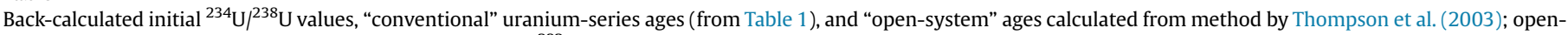
system ages in bold are samples with low $(\leq 0.0004 \mathrm{ppm}){ }^{232} \mathrm{Th}$ concentrations.

\begin{tabular}{|c|c|c|c|c|c|c|c|c|c|}
\hline $\begin{array}{l}\text { Sample and } \\
\text { location }\end{array}$ & Genus or species & $\begin{array}{l}\text { Depth below surface of } \\
\text { exposure }(\mathrm{m})\end{array}$ & $\begin{array}{l}\text { Calculated initial } \\
{ }^{234} \mathrm{U} /{ }^{238} \mathrm{U}\end{array}$ & \pm & $\begin{array}{l}\text { “Conventional” } \\
{ }^{230} \mathrm{Th} /{ }^{238} \mathrm{U} \text { age (ka) }\end{array}$ & \pm & $\begin{array}{l}\text { “Open-system” } \\
{ }^{230} \mathrm{Th} /{ }^{238} \mathrm{U} \text { age (ka) }\end{array}$ & \pm & Other notes \\
\hline \multicolumn{10}{|c|}{ PIER C, west-facing ditch exposure } \\
\hline Cuba 9-1B & Siderastrea sp. & 1.1 & 1.1577 & 0.0015 & 125.1 & 0.7 & 120.7 & 1.0 & \\
\hline Cuba $9-1 \mathrm{C}$ & Siderastrea sp. & 1.3 & 1.1658 & 0.0022 & 127.1 & 0.7 & 119.5 & 1.4 & \\
\hline Cuba 9-1D & Siderastrea sp. & 1.6 & 1.1699 & 0.0020 & 126.2 & 0.9 & 116.9 & 1.3 & \\
\hline Cuba 9-1E & Siderastrea sp. & 1.7 & 1.1675 & 0.0018 & 127.4 & 0.6 & 119.0 & 1.1 & \\
\hline Cuba 9-1F & Siderastrea sp. & 1.9 & 1.1574 & 0.0016 & 123.1 & 0.8 & 118.9 & 1.1 & \\
\hline Cuba $9-1 \mathrm{H}$ & Siderastrea sp. & 2.7 & 1.1743 & 0.0019 & 127.8 & 0.8 & 116.7 & 1.3 & High ${ }^{232} \mathrm{Th}$ \\
\hline \multicolumn{10}{|c|}{ PIER C, east-facing road cut exposure } \\
\hline Cuba 9-4a & Siderastrea sp. & 2.6 & 1.1641 & 0.0022 & 128.5 & 0.9 & 121.6 & 1.5 & High ${ }^{232} \mathrm{Th}$ \\
\hline Cuba 9-4a rpt & Siderastrea sp. & 2.6 & 1.1672 & 0.0021 & 128.8 & 0.6 & 120.4 & 1.3 & High ${ }^{232} \mathrm{Th}$ \\
\hline Cuba $9-4$ & Siderastrea sp. & 2.6 & 1.1674 & 0.0022 & 127.2 & 0.7 & 118.8 & 1.4 & \\
\hline Cuba 9-5 & Siderastrea sp. & 3.2 & 1.1576 & 0.0025 & 123.1 & 0.8 & 118.7 & 1.5 & High ${ }^{232} \mathrm{Th}$ \\
\hline Cuba 9-6 & Siderastrea sp. & 3.7 & 1.1586 & 0.0019 & 128.4 & 0.8 & 123.6 & 1.2 & \\
\hline Cuba 9-7 & Siderastrea sp. & 4.0 & 1.1579 & 0.0024 & 132.0 & 0.9 & 127.4 & 1.6 & \\
\hline Cuba 9-8 & Orbicella nancyi & 4.3 & 1.1598 & 0.0019 & 120.4 & 0.6 & 115.2 & 1.1 & High ${ }^{232} \mathrm{Th}$ \\
\hline Cuba 9-9 & Orbicella nancyi & 4.7 & 1.1880 & 0.0020 & 142.0 & 1.0 & 125.1 & 1.4 & \\
\hline Cuba 9-11 & Orbicella annularis & 5.7 & 1.1779 & 0.0019 & 141.6 & 1.2 & 128.7 & 1.4 & High ${ }^{232} \mathrm{Th}$ \\
\hline Cuba 9-12 & Orbicella annularis & 5.8 & 1.1698 & 0.0020 & 134.8 & 0.9 & 125.3 & 1.4 & \\
\hline Cuba 9-13 & Montastraea cavernosa & 6.2 & 1.1660 & 0.0020 & 138.1 & 0.8 & 130.1 & 1.3 & \\
\hline Cuba 9-14 & Siderastrea sp. & 6.4 & 1.1537 & 0.0022 & 127.2 & 0.8 & 124.5 & 1.5 & $\mathrm{High}^{232} \mathrm{Th}$ \\
\hline Cuba 9-15 & Eusmilia fastigata & 6.6 & 1.1598 & 0.0019 & 125.8 & 0.9 & 120.6 & 1.2 & $\mathrm{High}^{232} \mathrm{Th}$ \\
\hline Cuba 9-16 & Siderastrea sp. & 6.8 & 1.1628 & 0.0019 & 127.1 & 0.7 & 120.6 & 1.2 & High ${ }^{232} \mathrm{Th}$ \\
\hline Cuba 9-17 & Porites sp. & 7.2 & 1.1549 & 0.0027 & 132.9 & 0.9 & 129.5 & 1.7 & High ${ }^{232} \mathrm{Th}$ \\
\hline \multicolumn{10}{|c|}{ PIER C, early exploratory samples } \\
\hline Cuba 1 & Siderastrea sideria & $0-7$ & 1.1742 & 0.0024 & 127.9 & 0.9 & 116.8 & 1.5 & \\
\hline Cuba 2 & Siderastrea sideria & $0-7$ & 1.1780 & 0.0024 & 127.1 & 1.0 & 114.6 & 1.5 & \\
\hline Cuba 3 & Solenastrea bournoni & $0-7$ & 1.1643 & 0.0019 & 125.5 & 0.8 & 118.4 & 1.2 & \\
\hline \multicolumn{10}{|l|}{ HOSPITAL CAY } \\
\hline Cuba 29-1 & Colpophyllia sp. & $\sim 4.5$ & 1.1521 & 0.0020 & 119.4 & 0.6 & 117.3 & 1.3 & \\
\hline Cuba $29-2$ & Orbicella nancyi & $\sim 4.5$ & 1.1727 & 0.0020 & 130.6 & 0.9 & 120.0 & 1.3 & High ${ }^{232} \mathrm{Th}$ \\
\hline Cuba $29-3$ & Siderastrea sp. & $\sim 4.5$ & 1.1558 & 0.0022 & 128.5 & 0.9 & 124.8 & 1.5 & \\
\hline Cuba $29-4$ & Colpophyllia sp. & $\sim 4.5$ & 1.1688 & 0.0022 & 128.9 & 0.7 & 120.0 & 1.4 & \\
\hline \multicolumn{10}{|c|}{ SOUTH OF SHERMAN AVENUE } \\
\hline Cuba 14-A & Siderastrea sp. & $\sim 1.5$ & 1.1633 & 0.0020 & 136.5 & 0.9 & 129.7 & 1.3 & High ${ }^{232} \mathrm{Th}$ \\
\hline Cuba 14-B & Siderastrea sp. & $\sim 1.5$ & 1.1600 & 0.0024 & 128.8 & 0.8 & 123.4 & 1.5 & High ${ }^{232} \mathrm{Th}$ \\
\hline \multicolumn{10}{|c|}{ CABLE BEACH, main exposure } \\
\hline Cuba 23-7 & Diploria cf. D. strigosa & 3.6 & 1.1611 & 0.0022 & 131.9 & 0.8 & 126.0 & 1.5 & \\
\hline Cuba 23-11 & Diploria sp. & 4.55 & 1.1679 & 0.0023 & 133.7 & 0.8 & 125.0 & 1.5 & \\
\hline Cuba 23-6 & Diploria sp. & 4.9 & 1.1589 & 0.0028 & 133.7 & 1.0 & 128.7 & 1.9 & High ${ }^{232} \mathrm{Th}$ \\
\hline Cuba $23-5$ & Orbicella nancyi & 5.7 & 1.1996 & 0.0020 & 151.8 & 0.8 & 129.8 & 1.4 & \\
\hline Cuba $23-5 A$ & Diploria sp. & 5.9 & 1.1477 & 0.0019 & 132.2 & 0.8 & 131.9 & 1.3 & \\
\hline Cuba $23-4 \mathrm{~A}$ & Siderastrea sp. & 6.3 & 1.1764 & 0.0018 & 131.3 & 0.8 & 119.2 & 1.2 & \\
\hline Cuba $23-3$ & Orbicella nancyi & 7.35 & 1.1992 & 0.0022 & 145.1 & 1.0 & 123.6 & 1.5 & \\
\hline Cuba 23-2 & Diploria sp. & 7.35 & 1.1558 & 0.0021 & 132.3 & 0.8 & 128.7 & 1.4 & \\
\hline Cuba 23-1 & Diploria sp. & 7.8 & 1.1597 & 0.0022 & 133.3 & 0.8 & 128.0 & 1.5 & \\
\hline \multicolumn{10}{|c|}{ CABLE BEACH, cliff exposure $\sim 30 \mathrm{~m}$ to the north of main exposure } \\
\hline Cuba $23-10$ & Diploria cf. D. strigosa & & 1.1567 & 0.0019 & 126.2 & 0.9 & 122.1 & 1.3 & \\
\hline \multicolumn{10}{|c|}{ MARINE HILL, outer part } \\
\hline Cuba $7-2$ & Porites cf. P. asteroides & 0.9 & 1.1704 & 0.0017 & 133.1 & 0.8 & 123.5 & 1.1 & High ${ }^{232} \mathrm{Th}$ \\
\hline Cuba $7-3 \mathrm{~A}$ & Siderastrea sp. & 0.8 & 1.1696 & 0.0021 & 129.9 & 0.9 & 120.6 & 1.4 & \\
\hline Cuba 7-3B & Siderastrea sp. & 0.9 & 1.1700 & 0.0019 & 124.8 & 0.7 & 115.5 & 1.2 & \\
\hline Cuba 7-3C & Siderastrea sp. & 1.0 & 1.1709 & 0.0022 & 124.0 & 0.7 & 114.4 & 1.4 & \\
\hline \multicolumn{10}{|c|}{ CHAPMAN BEACH } \\
\hline Cuba 31-6 & Acropora palmata & 5.5 & 1.1688 & 0.0019 & 119.9 & 0.6 & 111.2 & 1.2 & \\
\hline Cuba $31-1$ & Acropora palmata & 7.2 & 1.1564 & 0.0019 & 125.2 & 0.9 & 121.3 & 1.2 & \\
\hline
\end{tabular}


for most corals are 5-10 ka younger than their apparent, uncorrected ages. Nevertheless, with one exception (Cuba 31-6 from Cable Beach, which is $111 \mathrm{ka}$ ), open-system coral ages still fall within the range of what would be considered to be MIS 5.5. When we apply the Thompson et al. (2003) criterion for significant ${ }^{232} \mathrm{Th}$ concentrations (eliminating those with concentrations higher than $\sim 0.0004 \mathrm{ppm}$ ), 31 samples remain. At Pier C, this additional culling results in somewhat better agreement of "corrected" open-system ages with stratigraphic position, particularly on the thick, eastfacing roadcut exposure (Fig. 10). If these corrections are accepted, the open-system ages indicate that reef growth during the last interglacial period at Guantanamo Bay began sometime before $\sim 130 \mathrm{ka}$ and continued until sometime just after $\sim 119 \mathrm{ka}$. At Cable Beach, open-system age calculations do not provide good agreement with the stratigraphic framework (Fig. 11). The most obvious reversal is with samples Cuba 23-3 (at the base of a large Orbicella nancyi colony), which gives an apparent open-system age of $\sim 124 \mathrm{ka}$, and Cuba 23-5 (at the top of the same colony), which gives an apparent open-system age of $\sim 130 \mathrm{ka}$. A similar situation occurs at outer Marine Hill, where a Siderastrea colony (Cuba 7-3A) gives a significantly older (open-system) age $(\sim 121 \mathrm{ka})$ than two colonies that are stratigraphically below it ( 115-114 ka). Other open-system ages, particularly at Cable Beach, are more difficult to assess, because of the three-dimensional nature of a reef. Younger corals can colonize openings in an existing reef, potentially at positions deeper (and thus appearing to be stratigraphically older) than coral colonies that are already established.

\subsection{Late Quaternary uplift rates}

There are three requirements for calculation of an uplift rate from marine terrace data: (1) the age of the terrace; (2) the elevation of the terrace, specifically that part of it that best represents sea level at the time of formation; and (3) paleo-sea level at the time of terrace formation. Field and laboratory data presented here provide (1) and (2); studies of emergent terraces from tectonically stable areas provide (3). Commonly, paleo-sea level at the peak of the last interglacial period is thought to have been +2 to +10 m relative to present, based on early studies by Veeh (1966) on tectonically stable coastlines. Many researchers assume a rough average of $+6 \mathrm{~m}$ and indeed some tectonically stable localities have last-interglacial sea level records remarkably close to this figure, such as Isla Guadalupe off Baja California and the Florida Keys (Muhs et al., 2002b, 2011). Nevertheless, it is now well established that glacial isostatic adjustment (GIA) processes will generate variations on this average eustatic value from coast to coast, depending on the physical geography of the continent or island, the extent of continental or insular shelves, the distance from former continental ice sheets, and other variables (Creveling et al., 2015; Lambeck et al., 2012).

In a recent study, Creveling et al. (2015) modeled the amount of departure of last interglacial sea-level elevations from purely eustatic values for a variety of localities around the world. In conducting this modeling, Creveling et al. (2015) considered eustatic values of both $+6 \mathrm{~m}$ and $+8 \mathrm{~m}$, relative to present. These investigators also considered what departures in sea level elevations would be from purely eustatic values at both the start (taken to be $\sim 127 \mathrm{ka}$ ) and end (taken to be $\sim 120 \mathrm{ka}$ ) of the last interglacial period. At $\sim 120 \mathrm{ka}$, departures from purely eustatic values of paleosea level could result in relative sea levels as high as $+11-13 \mathrm{~m}$ above present (at localities close to North American ice sheets) to as little as $+5-8 \mathrm{~m}$ above present (at Southern Hemisphere localities, distant from North American ice sheets). The areas closest to Guantanamo Bay, Cuba that were modeled in this study are Haiti and the Cayman Islands, where local, relative paleo-sea levels could have been $+8-9 \mathrm{~m}$ above present (assuming eustatic values of $+6 \mathrm{~m}$ ) to $+10-11 \mathrm{~m}$ above present (assuming eustatic values of $+8 \mathrm{~m}$ ) at the end of the of the last interglacial period. In order to (a) Pier C, west-facing ditch exposure

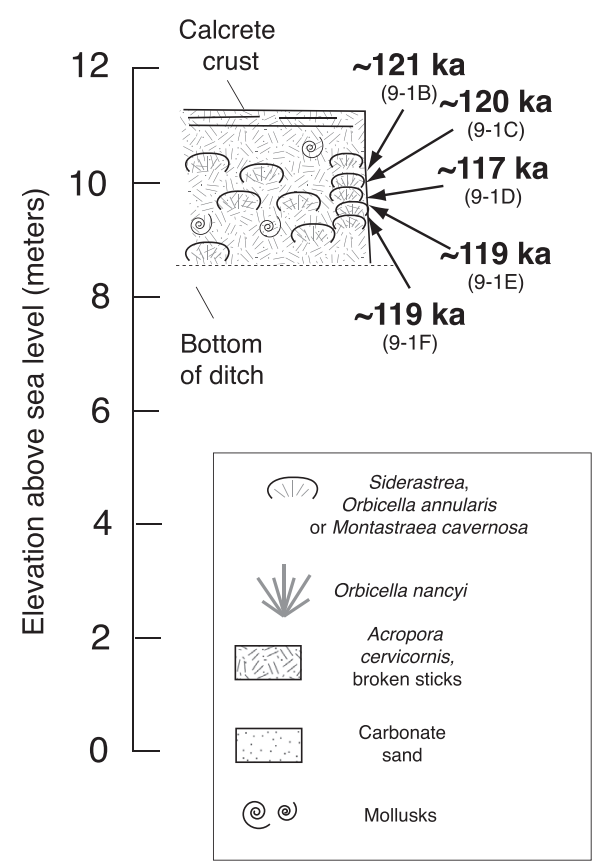

\section{(b) Pier C, east-facing roadcut exposure:}

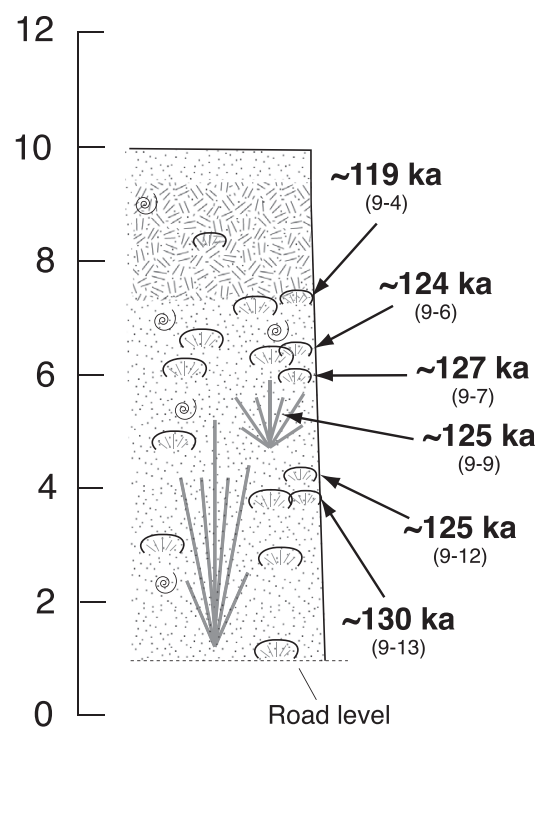

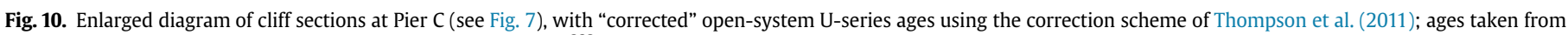
Table 2. Not shown are "corrected" U-series ages of corals with ${ }^{232}$ Th concentrations higher than $0.0004 \mathrm{ppm}$. 


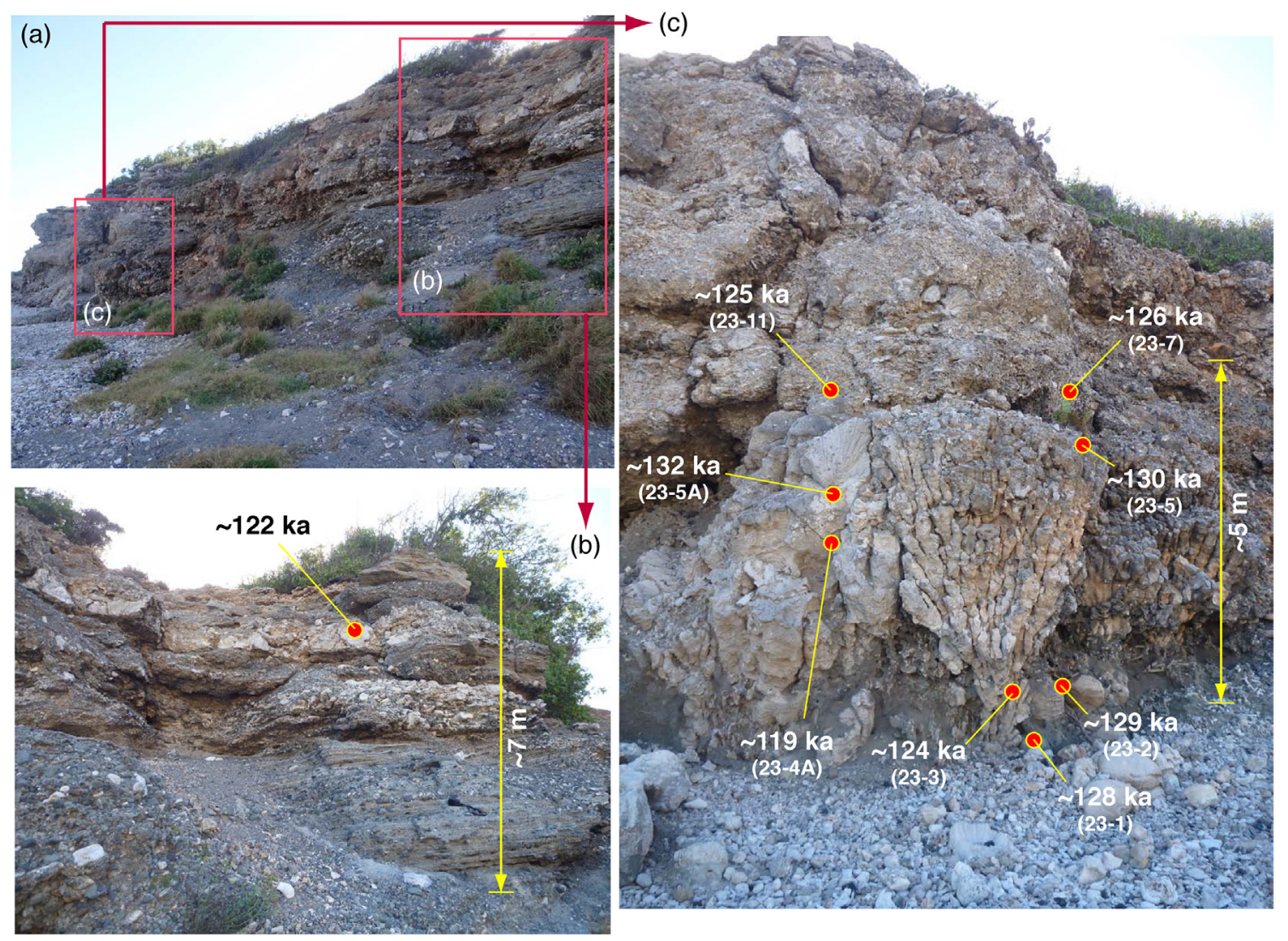

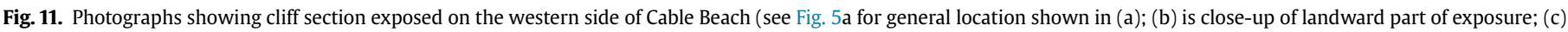

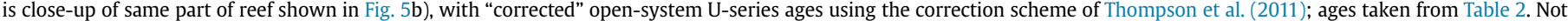
shown are "corrected" U-series ages of corals with ${ }^{232} \mathrm{Th}$ concentrations higher than $0.0004 \mathrm{ppm}$.

consider all possibilities, we calculated uplift rates using relative paleo-sea levels of $+6,+8,+9,+10$, and $+11 \mathrm{~m}$ and last-interglacial end times of $\sim 125 \mathrm{ka}, \sim 120 \mathrm{ka}$, and $115 \mathrm{ka}$ (Table 3). All three age estimates can be considered as possibilities, given both the "opensystem" and "closed-system" age estimates in Table 2. In addition, we also considered paleo-sea levels modeled by Creveling et al. (2015), again using nearby Haiti and the Cayman Islands, at the start of the last interglacial period, considered by these workers to be $\sim 127 \mathrm{ka}$. Sea levels at these times are modeled to be lower, ranging from $+4.2 \mathrm{~m}$ to $+7.5 \mathrm{~m}$ (Table 4 ).

It is important to note other criteria we used for calculation of uplift rates. As discussed earlier, we use the elevation data measured for four of our localities, Hospital Cay, Pier C, Cable Beach, and Chapman Beach (Fig. 8), with a +3-m adjustment for coral habitat depth (based on modern observations by Shinn et al. (1989)) added to the highest reef elevations at Hospital Cay, Pier C, and Chapman Beach (Table 3). This adjustment corresponds to the shallowest depths for optimum growth of coral taxa (Orbicella annularis, Montastraea cavernosa, Siderastrea sp., Diploria sp., and Colpophyllia sp.) that we analyzed from the highest elevations at these localities. Based on observations reported by Shinn et al. (1989), some of the coral species considered here have depth ranges that go deeper than this value (e.g., Diploria strigosa, optimum is $3-10 \mathrm{~m}$, but maximum is $\sim 40 \mathrm{~m}$; Siderastrea siderea, optimum is $3-20 \mathrm{~m}$, but maximum is $\sim 70 \mathrm{~m}$; Orbicella annularis, optimum is $3-45 \mathrm{~m}$, but maximum is $80 \mathrm{~m}$ ). If the corals we examined had been living at these greater possible depths, our calculated uplift rates would be too low. This is unlikely, however, because if the corals we studied were growing in water tens of meters below sea level, it is likely that we would have also observed marine deposits inland of those studied, at higher elevations, that had grown at shallower depths.

Results indicate that under virtually any scenario, uplift rates in the Guantanamo Bay area are fairly low (Tables 3 and 4). In all cases considered, late Quaternary uplift rates are $0.11 \mathrm{~m} / \mathrm{ka}$ or less and under some scenarios, less than a third of this value. Nevertheless, it is also clear from the results that some measureable amount of uplift has occurred at Guantanamo Bay since the last interglacial period, even using the most liberal estimates $(+11 \mathrm{~m})$ of paleo-sea level. An interpretation of uplift under any estimate of lastinterglacial paleo-sea level would be incorrect, however, if we modify our assumption of a minimum $+3 \mathrm{~m}$ coral habitat water depth adjustment to greater depths, as discussed above. However, several of our exposed, outer-coast localities (Fisherman Point, the Lighthouse, Cable Beach, and Windmill Beach) and one other (the "South of Sherman Avenue locality") have inner edge elevations that fall very close to the same elevations as our (minimally) corrected lagoonal facies deposits (Fig. 8). Therefore, while all possible uplift rates calculated are rather low, we do consider that there has been measurable late Quaternary uplift at Guantanamo Bay since the end of the last interglacial period.

\section{Discussion}

\subsection{Geomorphology, stratigraphy, and coral ages at Guantanamo Bay}

With the exception of a small, isolated fragment of ancient reef at $\sim 40 \mathrm{~m}$ elevation, there is no geomorphic evidence of more than one reef terrace in the Guantanamo Bay area. Indeed, the 
Table 3

Calculations of alternative late Quaternary tectonic uplift rates, Guantanamo Bay, Cuba: end of the last interglacial period.

\begin{tabular}{|c|c|c|c|c|c|c|c|}
\hline Locality & $\begin{array}{l}\text { Measured } \\
\text { elevation }(\mathrm{m})^{\mathrm{a}}\end{array}$ & Facies & $\begin{array}{l}\text { Corrected } \\
\text { elevation }(m)^{b}\end{array}$ & $\begin{array}{l}\text { Paleo-sea } \\
\text { level }(\mathrm{m})^{\mathrm{c}}\end{array}$ & $\begin{array}{l}\text { Amount of } \\
\text { uplift (m) }\end{array}$ & $\begin{array}{l}\text { Age } \\
\text { (ka) }\end{array}$ & $\begin{array}{l}\text { Uplift rate } \\
(\mathrm{m} / \mathrm{ka})\end{array}$ \\
\hline \multirow[t]{15}{*}{ Hospital Cay } & 10.8 & \multirow[t]{15}{*}{ Lagoonal } & 13.8 & 6 & 7.8 & 125 & 0.062 \\
\hline & 10.8 & & 13.8 & 8 & 5.8 & 125 & 0.046 \\
\hline & 10.8 & & 13.8 & 9 & 4.8 & 125 & 0.038 \\
\hline & 10.8 & & 13.8 & 10 & 3.8 & 125 & 0.030 \\
\hline & 10.8 & & 13.8 & 11 & 2.8 & 125 & 0.022 \\
\hline & 10.8 & & 13.8 & 6 & 7.8 & 120 & 0.065 \\
\hline & 10.8 & & 13.8 & 8 & 5.8 & 120 & 0.048 \\
\hline & 10.8 & & 13.8 & 9 & 4.8 & 120 & 0.040 \\
\hline & 10.8 & & 13.8 & 10 & 3.8 & 120 & 0.032 \\
\hline & 10.8 & & 13.8 & 11 & 2.8 & 120 & 0.023 \\
\hline & 10.8 & & 13.8 & 6 & 7.8 & 115 & 0.068 \\
\hline & 10.8 & & 13.8 & 8 & 5.8 & 115 & 0.050 \\
\hline & 10.8 & & 13.8 & 9 & 4.8 & 115 & 0.042 \\
\hline & 10.8 & & 13.8 & 10 & 3.8 & 115 & 0.033 \\
\hline & 10.8 & & 13.8 & 11 & 2.8 & 115 & 0.024 \\
\hline \multirow[t]{15}{*}{ Pier C } & 11.4 & \multirow[t]{15}{*}{ Lagoonal } & 14.4 & 6 & 8.4 & 125 & 0.067 \\
\hline & 11.4 & & 14.4 & 8 & 6.4 & 125 & 0.051 \\
\hline & 11.4 & & 14.4 & 9 & 5.4 & 125 & 0.043 \\
\hline & 11.4 & & 14.4 & 10 & 4.4 & 125 & 0.035 \\
\hline & 11.4 & & 14.4 & 11 & 3.4 & 125 & 0.027 \\
\hline & 11.4 & & 14.4 & 6 & 8.4 & 120 & 0.070 \\
\hline & 11.4 & & 14.4 & 8 & 6.4 & 120 & 0.053 \\
\hline & 11.4 & & 14.4 & 9 & 5.4 & 120 & 0.045 \\
\hline & 11.4 & & 14.4 & 10 & 4.4 & 120 & 0.037 \\
\hline & 11.4 & & 14.4 & 11 & 3.4 & 120 & 0.028 \\
\hline & 11.4 & & 14.4 & 6 & 8.4 & 115 & 0.073 \\
\hline & 11.4 & & 14.4 & 8 & 6.4 & 115 & 0.056 \\
\hline & 11.4 & & 14.4 & 9 & 5.4 & 115 & 0.047 \\
\hline & 11.4 & & 14.4 & 10 & 4.4 & 115 & 0.038 \\
\hline & 11.4 & & 14.4 & 11 & 3.4 & 115 & 0.030 \\
\hline \multirow[t]{15}{*}{ Cable Beach } & 14.3 & \multirow[t]{15}{*}{ Exposed outer coast } & 14.3 & 6 & 8.3 & 125 & 0.066 \\
\hline & 14.3 & & 14.3 & 8 & 6.3 & 125 & 0.050 \\
\hline & 14.3 & & 14.3 & 9 & 5.3 & 125 & 0.042 \\
\hline & 14.3 & & 14.3 & 10 & 4.3 & 125 & 0.034 \\
\hline & 14.3 & & 14.3 & 11 & 3.3 & 125 & 0.026 \\
\hline & 14.3 & & 14.3 & 6 & 8.3 & 120 & 0.069 \\
\hline & 14.3 & & 14.3 & 8 & 6.3 & 120 & 0.052 \\
\hline & 14.3 & & 14.3 & 9 & 5.3 & 120 & 0.044 \\
\hline & 14.3 & & 14.3 & 10 & 4.3 & 120 & 0.036 \\
\hline & 14.3 & & 14.3 & 11 & 3.3 & 120 & 0.028 \\
\hline & 14.3 & & 14.3 & 6 & 8.3 & 115 & 0.072 \\
\hline & 14.3 & & 14.3 & 8 & 6.3 & 115 & 0.055 \\
\hline & 14.3 & & 14.3 & 9 & 5.3 & 115 & 0.046 \\
\hline & 14.3 & & 14.3 & 10 & 4.3 & 115 & 0.037 \\
\hline & 14.3 & & 14.3 & 11 & 3.3 & 115 & 0.029 \\
\hline \multirow[t]{15}{*}{ Chapman Beach } & 14.8 & \multirow[t]{15}{*}{ Exposed outer coast } & 17.8 & 6 & 11.8 & 125 & 0.094 \\
\hline & 14.8 & & 17.8 & 8 & 9.8 & 125 & 0.078 \\
\hline & 14.8 & & 17.8 & 9 & 8.8 & 125 & 0.070 \\
\hline & 14.8 & & 17.8 & 10 & 7.8 & 125 & 0.062 \\
\hline & 14.8 & & 17.8 & 11 & 6.8 & 125 & 0.054 \\
\hline & 14.8 & & 17.8 & 6 & 11.8 & 120 & 0.098 \\
\hline & 14.8 & & 17.8 & 8 & 9.8 & 120 & 0.082 \\
\hline & 14.8 & & 17.8 & 9 & 8.8 & 120 & 0.073 \\
\hline & 14.8 & & 17.8 & 10 & 7.8 & 120 & 0.065 \\
\hline & 14.8 & & 17.8 & 11 & 6.8 & 120 & 0.057 \\
\hline & 14.8 & & 17.8 & 6 & 11.8 & 115 & 0.103 \\
\hline & 14.8 & & 17.8 & 8 & 9.8 & 115 & 0.085 \\
\hline & 14.8 & & 17.8 & 9 & 8.8 & 115 & 0.076 \\
\hline & 14.8 & & 17.8 & 10 & 7.8 & 115 & 0.068 \\
\hline & 14.8 & & 17.8 & 11 & 6.8 & 115 & 0.059 \\
\hline
\end{tabular}

a Highest elevation measured in the field at location given.

b Lagoonal facies localities and Chapman Beach given additional $3 \mathrm{~m}$ of paleo-sea level to account for minimum habitat depth.

c Paleo-sea level above present estimated from minimum eustatic component (6 m) and range of GIA-adjusted sea-level estimates from Haiti and Cayman Islands at the end of the last interglacial period (Creveling et al., 2015). 
Table 4

Calculations of alternative late Quaternary tectonic uplift rates, Guantanamo Bay, Cuba: start of the last interglacial period.

\begin{tabular}{|c|c|c|c|c|c|c|c|}
\hline Locality & $\begin{array}{l}\text { Measured } \\
\text { elevation }(\mathrm{m})^{\mathrm{a}}\end{array}$ & Facies & $\begin{array}{l}\text { Corrected } \\
\text { elevation }(m)^{b}\end{array}$ & $\begin{array}{l}\text { Paleo-sea } \\
\text { level }(\mathrm{m})^{\mathrm{c}}\end{array}$ & $\begin{array}{l}\text { Amount of } \\
\text { uplift (m) }\end{array}$ & $\begin{array}{l}\text { Age } \\
\text { (ka) }\end{array}$ & $\begin{array}{l}\text { Uplift rate } \\
(\mathrm{m} / \mathrm{ka})\end{array}$ \\
\hline \multirow[t]{4}{*}{ Hospital Cay } & 10.8 & \multirow[t]{4}{*}{ Lagoonal } & 13.8 & 4.2 & 9.6 & 127 & 0.076 \\
\hline & 10.8 & & 13.8 & 5.5 & 8.3 & 127 & 0.065 \\
\hline & 10.8 & & 13.8 & 6.2 & 7.6 & 127 & 0.060 \\
\hline & 10.8 & & 13.8 & 7.5 & 6.3 & 127 & 0.050 \\
\hline \multirow[t]{4}{*}{ Pier C } & 11.4 & \multirow[t]{4}{*}{ Lagoonal } & 14.4 & 4.2 & 10.2 & 127 & 0.080 \\
\hline & 11.4 & & 14.4 & 5.5 & 8.9 & 127 & 0.070 \\
\hline & 11.4 & & 14.4 & 6.2 & 8.2 & 127 & 0.065 \\
\hline & 11.4 & & 14.4 & 7.5 & 6.9 & 127 & 0.054 \\
\hline \multirow[t]{4}{*}{ Cable Beach } & 14.3 & \multirow[t]{4}{*}{ Exposed outer coast } & 14.3 & 4.2 & 10.1 & 127 & 0.080 \\
\hline & 14.3 & & 14.3 & 5.5 & 8.8 & 127 & 0.069 \\
\hline & 14.3 & & 14.3 & 6.2 & 8.1 & 127 & 0.064 \\
\hline & 14.3 & & 14.3 & 7.5 & 6.8 & 127 & 0.054 \\
\hline \multirow[t]{4}{*}{ Chapman Beach } & 14.8 & \multirow[t]{4}{*}{ Exposed outer coast } & 17.8 & 4.2 & 13.6 & 127 & 0.107 \\
\hline & 14.8 & & 17.8 & 5.5 & 12.3 & 127 & 0.097 \\
\hline & 14.8 & & 17.8 & 6.2 & 11.6 & 127 & 0.091 \\
\hline & 14.8 & & 17.8 & 7.5 & 10.3 & 127 & 0.081 \\
\hline
\end{tabular}

${ }^{a}$ Highest elevation measured in the field at location given.

b Lagoonal facies localities and Chapman Beach given additional $3 \mathrm{~m}$ of paleo-sea level to account for minimum habitat depth.

c Paleo-sea level above present estimated from two possible eustatic components ( $6 \mathrm{~m}$ and $8 \mathrm{~m}$ ) and range of GIA-adjusted sea-level estimates from Haiti and Cayman Islands at the start of the last interglacial period at $127 \mathrm{ka}$ (Creveling et al., 2015).

overwhelming geomorphic evidence, from both the appearance in the field (Figs. 4a and 5a) and from elevation measurements (Fig. 8) is that the bay is rimmed by a single terrace landform. Examination of the hills surrounding the bay, at elevations above this fossil reef, did not reveal any evidence of a higher terrace nor did we find detrital corals lying on bedrock surfaces above the last interglacial reef. Further, there is no evidence of any lower-elevation terraces.

Within exposures around the bay and the outer coast, which are numerous (Fig. 3), we did not observe any stratigraphic evidence of more than one high sea stand. Growth-position corals are commonly observed in these exposures, and appear to represent a reef that experienced more-or-less continuous upward growth without interruption during a single high-sea stand. We specifically looked for evidence of either subaerial exposure (paleosols, karst surfaces, laminar calcretes) or erosion (wave-cut benches), but found no such evidence in any exposure examined.

Early workers on Barbados mapped and described only a single reef terrace marking the peak of the last interglacial period, equivalent to MIS 5.5 (Bender et al., 1979; Broecker et al., 1968; Mesolella et al., 1969; Taylor and Mann, 1991). Later workers described as many as three separate terraces dating to MIS 5.5 (Schellmann and Radtke, 2004; Speed and Cheng, 2004). One could argue that on an island such as Barbados, which has experienced significant long-term uplift, small variations in sea level within an interglacial period, if they indeed occurred, in principle could be resolved in the geomorphic record of reef terraces. This is possible because relatively rapid uplift could move a terrace out of erosional reach of a subsequent high-sea stand. Following on this concept, it could also be argued that on a coast with a low uplift rate or one that is tectonically stable, two or more separate high-sea stands within an interglacial could easily be blurred into a single landform through erosion of the earlier high stand or stands by the latest high stand. Yet, Thompson et al. (2011), following on the earlier work of Chen et al. (1991), White et al. (1998), and Wilson et al. (1998), propose that at least two high-sea stands occurred within the last interglacial period, as recorded on the tectonically stable islands of the Bahamas. By this line of reasoning, such a record could be present at Guantanamo Bay. Nevertheless, we observed no such evidence in our studies. Other islands in the region, such as the tectonically stable Florida Keys and the slowly uplifting island of Curaçao (Muhs et al., 2011, 2012a), also offer no evidence of more than one high-sea stand within the last interglacial period. Resolution of this issue is important, however, as sea level fluctuations within an interglacial period, of a magnitude of several meters, would require significant ice sheet growth during a time when Northern Hemisphere summer insolation was high (Berger and Loutre, 1991; Otto-Bliesner et al., 2006; Overpeck et al., 2006).

On the other hand, it is possible that GIA processes in near-field or intermediate-field localities might preclude field recognition of two high-sea stands within the last interglacial period. Dutton and Lambeck (2012) modeled relative sea level during the last interglacial period for a variety of localities worldwide. These simulations demonstrate that some far-field localities, such as Australia, may have had a relative sea level that was high early in the last interglacial period, followed by a gradually falling sea level. In contrast, near-field localities of the Caribbean and western Atlantic, such as Bermuda, the Bahamas and Haiti, closer to North American ice sheets, may have had a relative sea level that was low in the early part of the last interglacial period, followed by a rapid rise to a maximum value very late in the same period. Given its location, Cuba's coastline likely would have experienced a relative sea level history similar to those of the Bahamas and Haiti. Thus, if there were a second, eustatic sea-level high-sea stand during the latter part of the last interglacial period, it would have been superimposed on the rising maximum sea level controlled by GIA processes at this time and a record of such an event may not be apparent in the field.

\subsection{Uplift rates at Guantanamo Bay and in the Caribbean region}

Using a range of options for age and paleo-sea level for four different localities around Guantanamo Bay, it can be concluded that uplift rates in this part of Cuba have been modest since the last interglacial period. Calculated uplift rates, while measurable, range from only $0.02-0.11 \mathrm{~m} / \mathrm{ka}$, supporting the concept that motion today along the Oriente fault is dominantly horizontal, accommodating much of the movement along the North America-Caribbean plate boundary. Although Rojas-Agramonte et al. (2005) 
hypothesized that uplift rates might be relatively high in the Santiago area (see earlier discussion), they also proposed that movement along the North America-Caribbean plate boundary since the Pliocene is transpressive, i.e., dominantly but not exclusively horizontal. Late Quaternary uplift rates in the range calculated here for Guantanamo Bay are similar to those in other regions characterized dominantly by strike-slip tectonics, such as much of the California coast west of the San Andreas Fault (see review by Muhs et al., 2014b). Uplift rates in coastal California are generally less than $0.5 \mathrm{~m} / \mathrm{ka}$ and many localities have uplift rates that are less than $0.2 \mathrm{~m} / \mathrm{ka}$. Exceptions to this include areas adjacent to restraining bends in faults, such as that near the Palos Verdes Hills fault, where late Quaternary uplift rates are as high as $\sim 0.7 \mathrm{~m} / \mathrm{ka}$, or seaward of the "Big Bend" area of the San Andreas Fault, where uplift rates are as high as $\sim 5.0 \mathrm{~m} / \mathrm{ka}$.

In order to put the uplift rates reported here into a regional context, we compiled data to calculate late Quaternary uplift rates based on emergent reef terraces from around the Caribbean. In this compilation, we included only those localities where mapped terraces are found with good elevation data and reliable U-series ages on corals date the terraces to the last interglacial period. Following Creveling et al. (2015), we chose an age of $\sim 120 \mathrm{ka}$ as the time of termination of the last interglacial period. Because the Caribbean and western Atlantic region spans a considerable latitudinal extent, local sea level elevations during the last interglacial period will vary due to GIA effects, combined with the eustatic component (Creveling et al., 2015; Lambeck et al., 2012). As discussed earlier, Creveling et al. (2015) modeled GIA effects for much of the region for both the beginning ( 127 ka) and end ( 120 ka) of the last interglacial period, as well as considering two estimates of the eustatic component of sea level $(+6 \mathrm{~m}$ and $+8 \mathrm{~m}$ of sea-level equivalent). For the end of the last interglacial period, at $\sim 120 \mathrm{ka}$, this results in local sea levels, including both the eustatic and GIAmodeled components, being as high as $\sim 11 \mathrm{~m}$ or as low as $\sim 6 \mathrm{~m}$ above sea level. We computed uplift rates for the region using both of these local paleo-sea level estimates.

It is apparent from this compilation that uplift rates in excess of $0.1 \mathrm{~m} / \mathrm{ka}$ are rare in the Caribbean region (Fig. 12). Most areas are either tectonically stable or uplifting very slowly. There are a few areas where uplift rates exceed $0.1 \mathrm{~m} / \mathrm{ka}$, however. Barbados has a last-interglacial reef crest that ranges in elevation from $\sim 15 \mathrm{~m}$ to 61 m (Taylor and Mann, 1991). Thus, considering paleo-sea levels as low as $+6 \mathrm{~m}$ and as high as $+11 \mathrm{~m}$ results in a range of uplift rates on this island from 0.03 to $0.46 \mathrm{~m} / \mathrm{ka}$. Taylor and Mann (1991) attributed variability in uplift rates on Barbados to local structures (folds) because of active shortening on this accretionary prism. Over much of northern Jamaica, what has been mapped as the Falmouth Formation (Henry, 1978a, 1978b) corresponds to what is likely the last interglacial reef terrace (Moore and Somayajulu, 1974; Szabo, 1979). In most places, the elevation of this terrace is only a few meters above sea level, but in the Oracabessa area (Fig. 2), it attains an elevation of 15 m (Cant, 1970, 1973). We hypothesize that the higher elevation of the Falmouth Formation here is due to uplift derived from a restraining bend in the fault that borders the northern shore of Jamaica (Figs. 1 and 2), but this requires additional testing with detailed elevation measurements and better geochronology. Haiti shows a range of uplift rates similar to Barbados, and like Barbados, the areas with the highest uplift rates are those coinciding with the axial traces of folds (Mann et al., 1995). These areas of active folding could, in turn, be a function of compression due to proximity of the areas to restraining bends in a fault that borders the northwestern part of Haiti (Fig. 12) and continues as the Oriente fault farther west (Fig. 2). Uplift of the northwestern coast of Haiti has been a long-term geologic process, demonstrated by the number and elevation of reef terraces in that area. Almost a century ago, Woodring et al. (1924) pointed out that there are as many as 28 uplifted reef terraces on the northwestern coast of Haiti, rising to an elevation of at least $\sim 430 \mathrm{~m}$. In a later study, Dodge et al. (1983) reported terraces on this part of Haiti as high as $\sim 600 \mathrm{~m}$. Such terraces likely date back to the early Pleistocene and imply that crustal compression and uplift, generated by the restraining bend in the adjacent fault, has been an ongoing process for a long time.

Although our data show that the rate of uplift in the Guantanamo Bay region is modest, higher rates of uplift are likely for other parts of the eastern and southern Cuban coast. From the air, we have observed multiple reef terraces off the eastern coast of Cuba, rising to an elevation of up to $\sim 400 \mathrm{~m}$ or more. The terraces are striking geomorphic features visible on satellite imagery (Fig. 13). To the best of our knowledge, these terraces have not been dated, but we hypothesize that the last interglacial terrace in this part of Cuba is at a significantly higher elevation than in the Guantanamo Bay area. In a reach of the southern coast of Cuba starting approximately $25 \mathrm{~km}$ to the west of Guantanamo Bay and continuing for an additional $\sim 50 \mathrm{~km}$ to Santiago de Cuba (Fig. 2), examination of satellite imagery reveals the presence of perhaps five or six terraces, rising to elevations of at least $\sim 100 \mathrm{~m}$ in places. Rojas-Agramonte et al. (2005) report terraces in this area as high as $\sim 200 \mathrm{~m}$, as discussed earlier. Still farther west, in the coastal region to the east of Cabo Cruz (Fig. 2), Taber (1934) reported multiple reef terraces. We have not observed these terraces personally, but examination of satellite imagery indicates there may be 10 or more terraces rising to elevations well over $\sim 250 \mathrm{~m}$. If these simple observations of what appears to be terrace geomorphology are correct, they imply higher rates of uplift than in our study area and suggest that the very low uplift rate around Guantanamo Bay actually may be anomalous for the southern coast of Cuba.

\subsection{Implications for GIA models}

What is also apparent from the compilation of uplift rates shown in Fig. 12 is that either many areas of the Caribbean and western Atlantic are subsiding or that some GIA-corrected paleosea level estimates generated by modeling are too high. For example, with GIA modeling, Lambeck et al. (2012) and Creveling et al. (2015) hypothesize that Bermuda had a last-interglacial sea level at 11-13 $\mathrm{m}$ above present, at the end of the high-sea stand. However, the highest undisputed last-interglacial deposits on Bermuda range from $+5 \mathrm{~m}$ to $+6 \mathrm{~m}$ (see summary in Vacher and Rowe, 1997, p. 78), and last-interglacial localities that we have measured ourselves on Bermuda range from $\sim 1.5 \mathrm{~m}$ to $\sim 7.7 \mathrm{~m}$. If the GIA modeling is correct, it is possible that Bermuda has been subsiding since the last interglacial period. Farther south, GIA-based estimates of last-interglacial paleo-sea level range from +9 to $11 \mathrm{~m}$ for the northern Caribbean and adjacent western Atlantic to +7-9 $\mathrm{m}$ for the southern Caribbean (Creveling et al., 2015; Lambeck et al., 2012). The implication of this is that a lastinterglacial shoreline lower than $+7 \mathrm{~m}$ on any Caribbean island or continental coastline must have subsided since the end of the last interglacial period. Based on reported maximum elevations of reef terraces, this would imply that most of the Florida Keys, many Bahamas islands, northern Cuba, the Yucatan Peninsula, the Cayman Islands, much of the northern coast of Jamaica, Isla Mona off Puerto Rico, Gonave Island off Haiti, and most of Puerto Rico's western coast have all subsided in the past 120,000 years (Fig. 12). Given the diverse geologic settings of these various islands and continental coastlines, some of which are in tectonically stable regions and others that are adjacent to major faults or even plate boundaries, this does not seem very likely. It is difficult to imagine what geologic process could bring about subsidence of several 


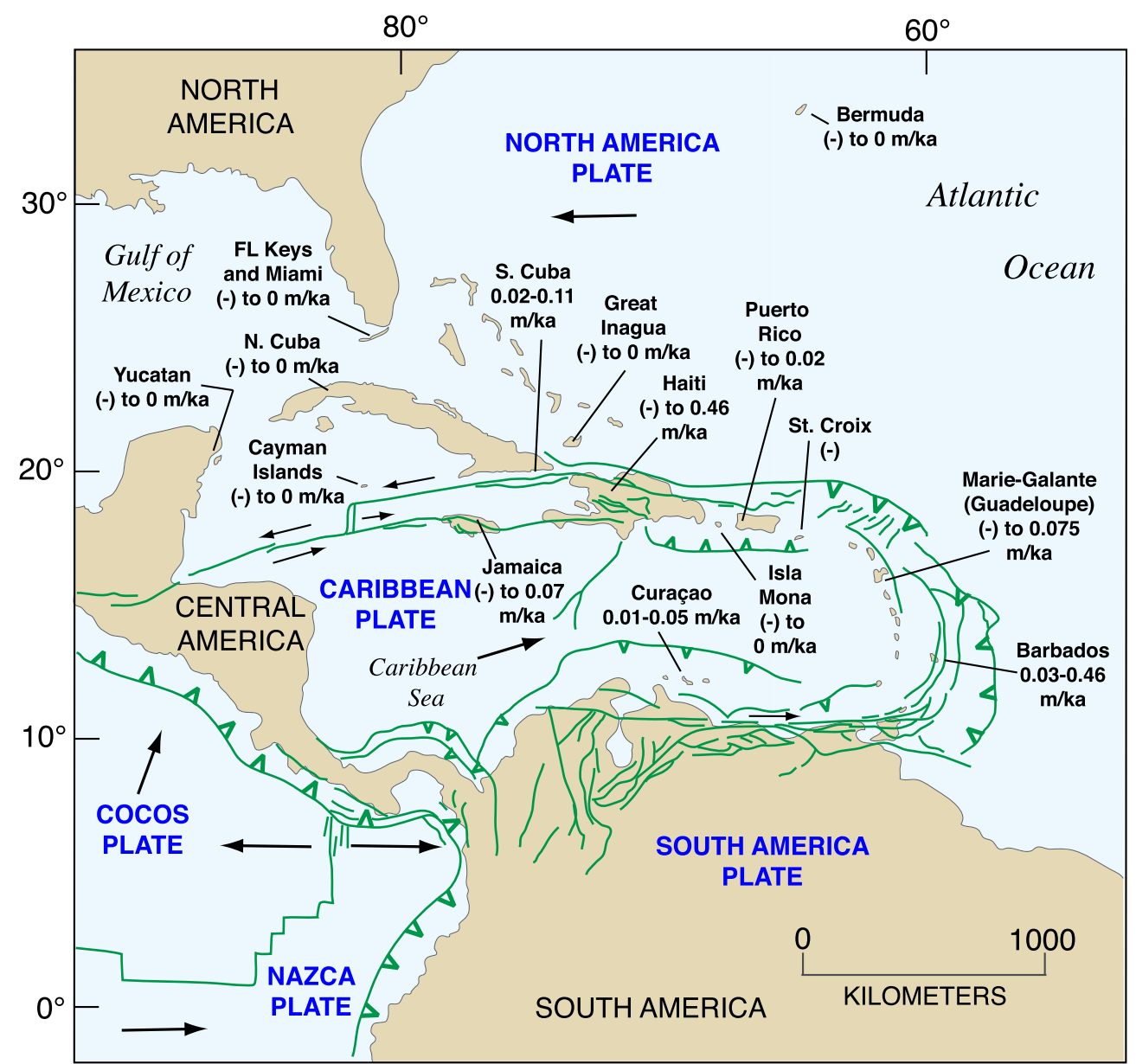

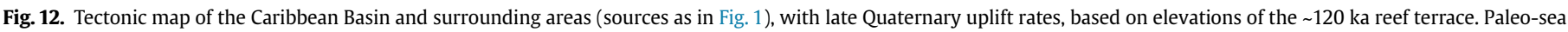

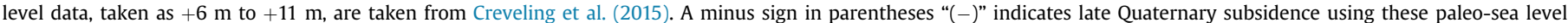

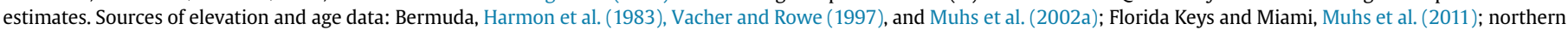

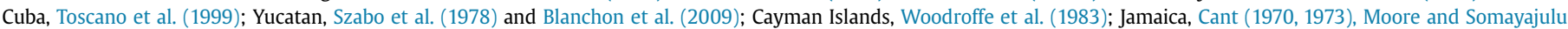

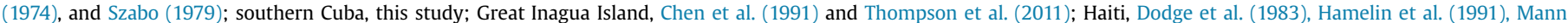

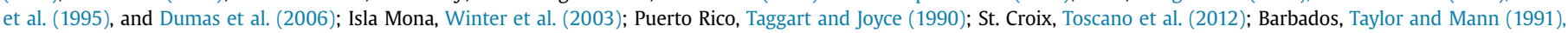
Gallup et al. (1994, 2002), Edwards et al. (1997), and Speed and Cheng (2004); Marie-Galante Island (Guadeloupe islands), Feuillet et al. (2004); Curaçao, Muhs et al. (2012a).

meters over the past $\sim 120,000$ years over a large region with such tectonic complexity. One exception to this is the island of St. Croix, where the last interglacial reef is about $9.5 \mathrm{~m}$ below sea level, based on coring and dating reported by Toscano et al. (2012). For this island, it is difficult to explain the position of the last interglacial reef by any process other than subsidence. For all the other localities around the region, however, the simplest explanation is that some of the GIA-modeled estimates of paleo-sea level reported by Lambeck et al. (2012) and Creveling et al. (2015) are too high and require revision of the boundary conditions of the models.

The results presented here do support some other aspects of GIA modeling, however. Based on the low uplift rates reported here, coral reefs dating to the $\sim 100 \mathrm{ka}$ (MIS 5.3) or $\sim 80 \mathrm{ka}$ (MIS 5.1) sea stands should not be emergent in the Guantanamo Bay area. The GIA modeling of Potter and Lambeck (2003) indicates that on tectonically stable Bermuda and the U.S. Atlantic Coastal Plain, 80 ka marine deposits should be emergent. Field and laboratory studies indicate that this is in fact the case (Muhs et al., 2002a; Wehmiller et al., 2004). Potter and Lambeck's (2003) modeling also indicates that at $\sim 80 \mathrm{ka}$, paleo-sea level in southern Cuba could have been $\sim 12 \mathrm{~m}$ below present. If the uplift rates reported here $(0.02-0.11 \mathrm{~m} / \mathrm{ka})$ are correct, then an $\sim 80 \mathrm{ka}$ reef terrace should have experienced only $\sim 1.6-\sim 8.2 \mathrm{~m}$ of uplift. With a paleo-sea level at $\sim 12 \mathrm{~m}$ below present, this reef should still be submerged off of Guantanamo Bay. Based on our observations and dating, the lack of any evidence of a reef younger than $\sim 120 \mathrm{ka}$ at Guantanamo Bay supports the GIA modeling.

\section{Conclusions}

There has been considerable interest in the nature of the North America-Caribbean plate boundary along the northern margin of the Caribbean region. Previous investigators have suggested that the nature of the plate boundary in this area has evolved over time, but has been dominated by a transpressive regime since about the Pliocene. If so, we hypothesized that there should be at least a small, but measurable component of vertical movement in this part of southern Cuba. Guantanamo Bay, Cuba is situated in this area. We studied a number of sections exposing an unusually well preserved emergent reef terrace around Guantanamo Bay to determine its stratigraphy, elevation range, and age. An inner, protected, lagoonal facies of reef sediments is recognized, with abundant corals in growth position and elevations as high as $\sim 11-12 \mathrm{~m}$. An exposed, outer-coast reef facies is also recognized, with wave-cut benches in places as well as other species of corals in growth position; inner edges of outer-coast facies deposits are as high as $\sim 14 \mathrm{~m}$. Sixty-five 


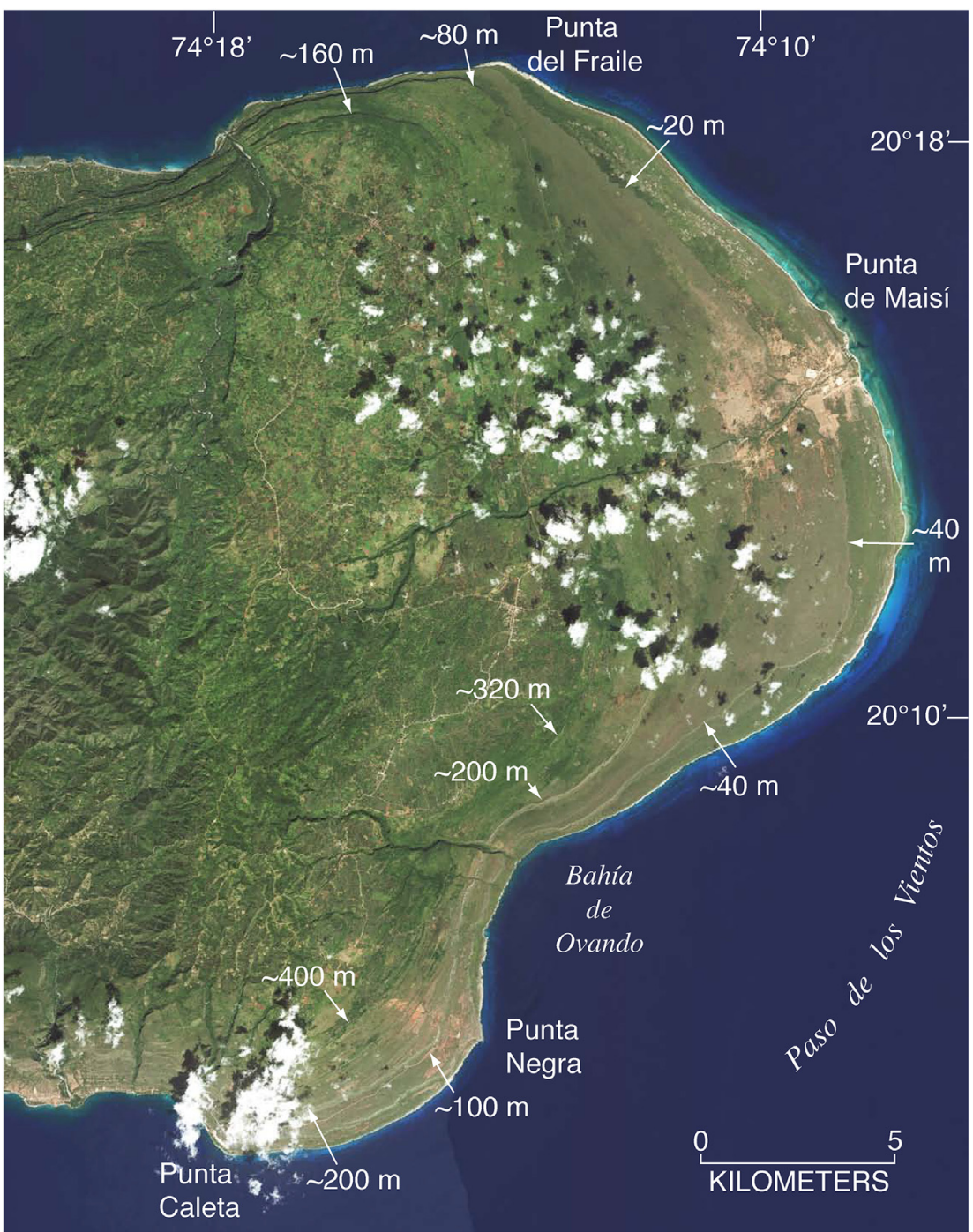

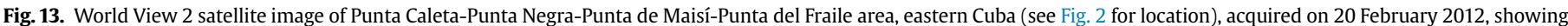

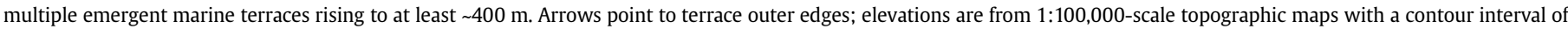
$40 \mathrm{~m}$. Satellite image used courtesy of Digital Globe.

uranium-series analyses of unrecrystallized corals from six localities were generated. Some of these specimens show secondary additions of $U$, some show inheritance of Th, and others show elevated initial ${ }^{234} \mathrm{U} /{ }^{238} \mathrm{U}$ values. Nevertheless, about a dozen corals do not have these characteristics and have U-series ages ranging from $133 \mathrm{ka}$ to $119 \mathrm{ka}$. Use of an open-system "correction" scheme yields a larger suite of coral age estimates, but the range of ages is similar, from $\sim 130$ ka to $\sim 119 \mathrm{ka}$. Thus, by either method, ages of corals correlate this reef to the peak of the last interglacial period, MIS 5.5. Neither stratigraphic data nor U-series ages support the idea, reported from other localities, that there were two separate high stands of sea during MIS 5.5. Using estimates of paleo-sea level during MIS $5.5(+6$ to $+11 \mathrm{~m})$ and possible ages $(\sim 125 \mathrm{ka}$ to $\sim 115 \mathrm{ka})$ yields a range of late Quaternary uplift rates of $0.02-0.11 \mathrm{~m} / \mathrm{ka}$ for the Guantanamo Bay area. This range of estimates supports the hypothesis that the tectonic uplift rate is low adjacent to the Oriente fault of this part of the North AmericaCaribbean plate boundary. Nevertheless, in areas of eastern and southern Cuba, to the east and west of Guantanamo Bay, aerial views and examination of satellite imagery show that there are multiple terraces, some rising to more than $\sim 100 \mathrm{~m}$ (west of
Guantanamo Bay) and $\sim 400 \mathrm{~m}$ (east of Guantanamo Bay). In these areas, we hypothesize that there is a greater vertical component of movement and the low uplift rate at Guantanamo Bay itself may be something of an anomaly for this part of Cuba.

Using published data from other Caribbean islands and continental coastlines, we show that with the exception of Haiti and Barbados, uplift rates are low or zero on most insular and continental coastlines of the Caribbean region and adjacent parts of the western Atlantic. We note, however, that some recently published paleo-sea level estimates for the Caribbean region that account for GIA processes may be too high. Use of the upper ranges of these estimates would imply that many islands and continental coastlines have subsided since the close of the last interglacial period, a scenario that we consider unlikely over such a vast and tectonically diverse region. Nevertheless, our data support other aspects of GIA modeling. Given the low uplift rates reported here combined with estimated paleo-sea level (modeled for GIA effects), there should be no evidence of emergent $\sim 80 \mathrm{ka}$ marine deposits at Guantanamo Bay, in contrast to localities farther north, such as Bermuda and the U.S. Atlantic Coastal Plain. Our field and laboratory data indicate that there is no emergent reef around Guantanamo Bay that is 
younger than $\sim 120 \mathrm{ka}$, which supports the GIA modeling.

\section{Acknowledgments}

This study was supported by the Climate and Land Use Change Research and Development Program of the U.S. Geological Survey (USGS) and is a contribution to the "Geologic records of high sea levels" project (http://gec.cr.usgs.gov/projects/sealevels/). It is a pleasure to thank the many people who helped us. First and foremost, we thank Michael R. McCord (former Environmental Director, U.S. Naval Base Guantanamo Bay, Cuba), who arranged our trips, provided logistical support, and gave us much encouragement for doing the study. We also wish to thank Mark Gettel (Environmental Office, U.S. Naval Base Guantanamo Bay, Cuba), who also provided logistical support; Gary Skipp (USGS), who X-rayed all the corals; Randy Schumann (USGS), who post-processed the GPS data; and Darren Van Sistine (USGS), who georeferenced Meinzer's geologic map of the area and provided the satellite image shown in Fig. 13. We thank Digital Globe for allowing use of the satellite image in Fig. 13. Margaret Berry and Janet Slate, both of the USGS, made very helpful comments on an earlier version of the paper, as did two anonymous QSR reviewers; thanks to all for these efforts. Any use of trade, product, or firm names is for descriptive purposes only and does not imply endorsement by the U.S. Government.

\section{References}

Academia de Ciencias de Cuba, Instituto de Geología y Paleontología, 1988. Mapa Geológico de Cuba, 40 sheets, scale, 1: 250,000.

Agassiz, A., 1894. A reconnoissance [sic] of the Bahamas and of the elevated reefs of Cuba in the steam yacht "Wild Duck," January to April, 1893. Bull. Mus. Comp. Zoology 26, 1-203.

Bard, E., Hamelin, B., Fairbanks, R.G., Zindler, A., 1990. Calibration of the ${ }^{14} \mathrm{C}$ timescale over the past 30,000 years using mass spectrometric U-Th ages from Barbados corals. Nature 345, 405-410.

Bender, M.L., Fairbanks, R.G., Taylor, F.W., Matthews, R.K., Goddard, J.G., Broecker, W.S., 1979. Uranium-series dating of the Pleistocene reef tracts of Barbados, west Indies. Geol. Soc. Am. Bull. Part I 90, 577-594.

Berger, A., Loutre, M.F., 1991. Insolation values for the climate of the last 10 million years. Quat. Sci. Rev. 10, 297-317.

Blanchon, P., Eisenhauer, A., Fietzke, J., Liebetrau, V., 2009. Rapid sea-level rise and reef back-stepping at the close of the last interglacial highstand. Nature 458 $881-885$.

Bloom, A.L., Broecker, W.S., Chappell, J.M.A., Matthews, R.K., Mesolella, K.J., 1974 Quaternary sea level fluctuations on a tectonic coast: new ${ }^{230} \mathrm{Th} /{ }^{234} \mathrm{U}$ dates from the Huon Peninsula, New Guinea. Quat. Res. 4, 185-205.

Broecker, W.S., Thurber, D.L., 1965. Uranium-series dating of corals and oolites from Bahaman and Florida Key limestones. Science 149, 58-60.

Broecker, W.S., Thurber, D.L., Goddard, J., Ku, T.-L., Matthews, R.K., Mesolella, K.J., 1968. Milankovitch hypothesis supported by precise dating of coral reefs and deep-sea sediments. Science 159, 297-300.

Budd, A.F., Stemann, T.A., Johnson, K.G., 1994. Stratigraphic distributions of genera and species of Neogene to Recent Caribbean reef corals. J. Paleontology 68, 951-977.

Budd, A.F., Fukami, H., Smith, N.D., Knowlton, N., 2012. Taxonomic classification of the reef coral family Mussidae (Cnidaria: Anthozoa: Scleractinia). Zoological J. Linn. Soc. 166, 465-529.

Cabrera, M., Peñalver, L.L., 2001. Contribución a la estratigrafía de los depósitos cuaternarios de Cuba. Rev. Cuaternario Geomorfol. 15, 37-49.

Calais, E., Perrot, J., Mercier de Lépinay, B., 1998. Strike-slip tectonics and seismicity along the northern Caribbean plate boundary from Cuba to Hispaniola. Geol. Soc. Am. Special Pap. 326, 125-141.

Cant, R.V., 1970. Pleistocene Terraces Near Oracabessa. in: International Field Institute Guidebook to the Caribbean Island-arc System. American Geological Institute, Washington, D.C., pp. 40-43

Cant, R.V., 1973. Jamaica's Pleistocene reef terraces. Geol. Mijnb. 52, 157-160.

Chen, J.H., Edwards, R.L., Wasserburg, G.J., 1986. ${ }^{238} \mathrm{U},{ }^{234} \mathrm{U}$, and ${ }^{232} \mathrm{Th}$ in seawater. Earth Planet. Sci. Lett. 80, 241-251.

Chen, J.H., Curran, H.A., White, B., Wasserburg, G.J., 1991. Precise chronology of the last interglacial period: ${ }^{234} \mathrm{U}_{-}{ }^{230} \mathrm{Th}$ data from fossil coral reefs in the Bahamas. Geol. Soc. Am. Bull. 103, 82-97.

Cheng, H., Edwards, R.L., Shen, C.-C., Polyak, V.J., Asmerom, Y., Woodhead, J., Hellstrom, J., Wang, Y., Kong, X., Spötl, C. Wang, X., Alexander Jr., E.C., 2013 Improvements in ${ }^{230} \mathrm{Th}$ dating, ${ }^{230} \mathrm{Th}$ and ${ }^{234} \mathrm{U}$ half-life values, and U-Th isotopic measurements by multi-collector inductively coupled plasma mass spectrometry. Earth Planet. Sci. Lett. 371-372, 82-91.
Clark, P.U., Huybers, P., 2009. Interglacial and future sea level. Nature 462, 856-857. Creveling, J.R., Mitrovica, J.X., Hay, C.C., Austermann, J., Kopp, R.E., 2015. Revisiting tectonic corrections applied to Pleistocene sea-level highstands. Quat. Sci. Rev. 111, $72-80$.

Crosby, W.O., 1882. On the elevated coral reefs of Cuba. Proc. Boston Soc. Nat. Hist. 124-130, 22.

Cross, T.S., Cross, B.W., 1983. U, Sr, and Mg in Holocene and Pleistocene corals A. palmata and M. annularis. J. Sediment. Petrology 53, 587-594.

Cutler, K.B., Edwards, R.L., Taylor, F.W. Cheng, H., Adkins, A., Gallup, C.D., Cutler, P.M., Burr, G.S., Bloom, A.L., 2003. Rapid sea-level fall and deep-ocean temperature change since the last interglacial period. Earth Planet. Sci. Lett. 206, 253-271.

Darwin, C., 1889. The Structure and Distribution of Coral Reefs, third ed. Smith, Elder \& Co, London, p. 344.

Delanghe, D., Bard, E., Hamelin, B., 2002. New TIMS constraints on the uranium-238 and uranium-234 in seawaters from the main ocean basins and the Mediterranean Sea. Mar. Chem. 80, 79-93.

Dodge, R.E., Fairbanks, R.G., Benninger, L.K., Maurrasse, F., 1983. Pleistocene sea levels from raised coral reefs of Haiti. Science 219, 1423-1425.

Dumas, B., Hoange, C.T., Raffy, J., 2006. Record of MIS 5 sea-level highstands based on U/Th dated coral terraces of Haiti. Quat. Int. 145-146, 106-118.

Dutton, A., Lambeck, K., 2012. Ice volume and sea level during the last interglacial. Science 337, 216-219.

Dutton, A., Webster, J.M., Zwartz, D., Lambeck, K., Wohlfarth, B., 2015. Tropical tales of polar ice: evidence of Last Interglacial polar ice sheet retreat recorded by fossil reefs of the granitic Seychelles islands. Quat. Sci. Rev. 107, 182-196.

Edwards, R.L., Cheng, H., Murrell, M.T., Goldstein, S.J., 1997. Protactinium-231 dating of carbonates by thermal ionization mass spectrometry: implications for Quaternary climate change. Science 276, 782-786.

Edwards, R.L., Gallup, C.D., Cheng, H., 2003. Uranium-series dating of marine and lacustrine carbonates. Rev. Mineralogy Geochem. 52, 363-405.

Esat, T.M., McCulloch, M.T., Chappell, J., Pillans, B., Omura, A., 1999. Rapid fluctuations in sea level recorded at Huon Peninsula during the penultimate deglaciation. Science 283, 197-201.

Feuillet, N., Tapponnier, P., Manighetti, I., Villemant, B., King, G.C.P., 2004. Differential uplift and tilt of Pleistocene reef platforms and Quaternary slip rate on the Morne-Piton normal fault (Guadeloupe, French West Indies). J. Geophys. Res. 109, B02404. https://doi.org/10.1029/2003JB002496.

Gallup, C.D., Edwards, R.L., Johnson, R.G., 1994. The timing of high sea levels over the past 200,000 years. Science 263, 796-800.

Gallup, C.D., Cheng, H., Taylor, F.W., Edwards, R.L., 2002. Direct determination of the timing of sea level change during Termination II. Science 295, 310-313.

Hamelin, B., Bard, E., Zindler, A., Fairbanks, R.G., 1991. ${ }^{234} \mathrm{U} /{ }^{238} \mathrm{U}$ mass spectrometry of corals: how accurate is the U-Th age of the last interglacial period? Earth Planet. Sci. Lett. 106, 169-180.

Harmon, R.S., Mitterer, R.M., Kriausakul, N., Land, L.S., Schwarcz, H.P., Garrett, P., Larson, G.J., Vacher, H.L., Rowe, M., 1983. U-series and amino-acid racemization geochronology of Bermuda: implications for eustatic sea-level fluctuation over the past 250,000 years. Palaeogeogr. Palaeoclimatol. Palaeoecol. 44, 41-70.

Henry, L.A., 1978a. Port Maria: Geological Sheet 21. Mines and Geology Division, Jamaica Ministry of Mining and Natural Resources scale1:50,000.

Henry, L.A., 1978b. Ocho Rios: Geological Sheet 18. Mines and Geology Division, Jamaica Ministry of Mining and Natural Resources scale1:50,000.

Hill, R.T., 1895. Notes on the geology of the Island of Cuba, based on a reconnaissance made for Alexander Agassiz. Bull. Mus. Comp. Zoology 16, 243-288.

Horsfield, W.T., 1975. Quaternary vertical movements in the greater Antilles. Geol. Soc. Am. Bull. 86, 933-938.

Kopp, R.E., Simons, F.J., Mitrovica, J.X., Maloof, A.C., Oppenheimer, M., 2009. Probabilistic assessment of sea level during the last interglacial stage. Nature 462 863-868.

Lambeck, K., Purcell, A., Dutton, A., 2012. The anatomy of interglacial sea levels: the relationship between sea levels and ice volumes during the Last Interglacial. Earth Planet. Sci. Lett. 315-316, 4-11.

Ludwig, K.R., 2001. Users Manual for Isoplot/Ex, Rev. 2.49. Berkeley Geochronology Center, Berkeley, California, p. 55. Special Publication No. 1a.

Ludwig, K.R., Paces, J.B., 2002. Uranium-series dating of pedogenic silica and carbonate, Crater Flat, Nevada. Geochimica Cosmochimica Acta 66, 487-506.

Ludwig, K.R., Wallace, A.R., Simmons, K.R., 1985. The Schwartzwalder uranium deposit, II: age of uranium mineralization and Pb-isotope constraints on genesis. Econ. Geol. 80, 1858-1871.

Ludwig, K.R., Simmons, K.R., Szabo, B.J., Winograd, I.J., Landwehr, J.M., Riggs, A.C., Hoffman, R.J., 1992. Mass-spectrometric ${ }^{230} \mathrm{Th}-{ }^{234} \mathrm{U}-{ }^{238} \mathrm{U}$ dating of the Devils Hole calcite vein. Science 258, 284-287.

Ludwig, K.R., Muhs, D.R., Simmons, K.R., Halley, R.B., Shinn, E.A., 1996. Sea level records at $\sim 80$ ka from tectonically stable platforms: Florida and Bermuda. Geology 24, 211-214.

Mann, P., 2007. Global catalogue, classification and tectonic origins of restrainingand releasing bends on active and ancient strike-slip fault systems. Geol. Soc. Lond. Special Publ. 290, 13-142.

Mann, P., Taylor, F.W., Edwards, R.L., Ku, T.-L., 1995. Actively evolving microplate formation by oblique collision and sideways motion along strike-slip faults: an example from the northeastern Caribbean plate margin. Tectonophysics 246, $1-69$.

Mann, P., Calais, E., Ruegg, J.-C., DeMets, C., Jansma, P.E., Mattioli, G.S., 2002. Oblique collision in the northeastern Caribbean from GPS measurements and geological 
observations. Tectonics 21 (6). https://doi.org/10.1029/2001TC001304.

Martin, L., Suguio, K., Flexor, J.-M., 1988. Hauts niveaux marins Pleistocenes du littoral Bresilien. Palaeogeogr. Palaeoclimatol. Palaeoecol. 68, 231-239.

Martinson, D.G., Pisias, N.G., Hays, J.D., Imbrie, J., Moore Jr., T.C., Shackleton, N.J., 1987. Age dating and the orbital theory of the ice ages: Development of a highresolution 0 to 300,000-year chronostratigraphy. Quat. Res. 27, 1-29.

Meinzer, O.E., 1933. Geological reconnaissance adjacent to Guantanamo bay, Cuba. J. Wash. Acad. Sci. 23, 246-260.

Mesolella, K.J., Matthews, R.K., Broecker, W.S., Thurber, D.L., 1969. The astronomical theory of climatic change: Barbados data. J. Geol. 77, 250-274.

Milne, G.A., Mitrovica, J.X., 2008. Searching for eustasy in deglacial sea-level histories. Quat. Sci. Rev. 27, 2292-2302.

Moore, W.S., Somayajulu, B.L.K., 1974. Age determinations of fossil corals using ${ }^{230} \mathrm{Th} /{ }^{234} \mathrm{Th}$ and ${ }^{230} \mathrm{Th} /{ }^{227} \mathrm{Th}$. J. Geophys. Res. 79, 5065-5068.

Muhs, D.R., Simmons, K.R., 2017. Taphonomic problems in reconstructing sea-level history from the late Quaternary marine terraces of Barbados. Quat. Res. 88, 409-429.

Muhs, D.R., Simmons, K.R., Steinke, B., 2002a. Timing and warmth of the last interglacial period: new U-series evidence from Hawaii and Bermuda and a new fossil compilation for North America. Quat. Sci. Rev. 21, 1355-1383.

Muhs, D.R., Simmons, K.R., Kennedy, G.L., Rockwell, T.K., 2002b. The last interglacial period on the Pacific Coast of North America: timing and paleoclimate. Geol. Soc. Am. Bull. 114, 569-592.

Muhs, D.R., Simmons, K.R., Schumann, R.R., Halley, R.B., 2011. Sea-level history of the past two interglacial periods: new evidence from U-series dating of reef corals from south Florida. Quat. Sci. Rev. 30, 570-590.

Muhs, D.R., Pandolfi, J.M., Simmons, K.R., Schumann, R.R., 2012a. Sea-level history of past interglacial periods from uranium-series dating of corals, Curaçao, Leeward Antilles islands. Quat. Res. 78, 157-169.

Muhs, D.R., Simmons, K.R., Schumann, R.R., Groves, L.T., Mitrovica, J.X., Laurel, D., 2012b. Sea-level history during the Last Interglacial complex on San Nicolas Island, California: implications for glacial isostatic adjustment processes, paleozoogeography and tectonics. Quat. Sci. Rev. 37, 1-25.

Muhs, D.R., Meco, J., Simmons, K.R., 2014a. Uranium-series ages of corals, sea level history, and palaeozoogeography, Canary Islands, Spain: an exploratory study for two Quaternary interglacial periods. Palaeogeogr. Palaeoclimatol. Palaeoecol. 394, 99-118.

Muhs, D.R., Simmons, K.R., Schumann, R.R., Groves, L.T., DeVogel, S.B., Minor, S.A., Laurel, D., 2014b. Coastal tectonics on the eastern margin of the Pacific rim: late Quaternary sea-level history and uplift rates, Channel Islands National Park, California, USA. Quat. Sci. Rev. 105, 209-238.

Murray-Wallace, C.V., Woodroffe, C.D., 2014. Quaternary Sea Level Changes: a Global Perspective. Cambridge University Press, Cambridge, p. 484.

O'Leary, M.J., Hearty, P.J., Thompson, W.G., Raymo, M.E., Mitrovica, J.X. Webster, J.M., 2013. Ice sheet collapse following a prolonged period of stable sea level during the last interglacial. Nat. Geosci. 6, 796-800.

Otto-Bliesner, B.L., Marshall, S.J., Overpeck, J.T., Miller, G.H., Hu, A., CAPE last interglacial project members, 2006. Simulating Arctic climate warmth and icefield retreat in the last interglaciation. Science 311, 1751-1753.

Overpeck, J.T., Otto-Bliesner, B.L., Miller, G.H., Muhs, D.R., Alley, R.B., Kiehl, J.T., 2006. Paleoclimatic evidence for future ice-sheet instability and rapid sea-level rise. Science 311, 1747-1750.

Pandolfi, J.M., 2007. A new, extinct Pleistocene reef coral from the Montastraea "annularis" species complex. J. Paleontology 81, 472-482.

Pandolfi, J.M., Jackson, J.B.C., Geister, J., 2001. Geologically sudden extinction of two widespread late Pleistocene Caribbean reef corals. In: Jackson, J.B.C., Lidgard, S., McKinney, F.K. (Eds.), Evolutionary Patterns: Growth, Form, and Tempo in the Fossil Record. University of Chicago Press, Chicago, pp. 120-158.

Pindell, J.L., Kennan, L., 2009. Tectonic evolution of the Gulf of Mexico, Caribbean and northern South America in the mantle reference frame: an update. Geol. Soc. Lond. Special Publ. 328, 1-55.

Portell, R.W., McCleskey, T., Toomey, J.K., 2008. Fossil invertebrates of the U.S. Naval Station Guantanamo Bay, Cuba, Part 1, Pleistocene Marine mollusca. Division of Invertebrate Paleontology, Florida Museum of Natural History, $32 \mathrm{pp}$.

Portell, R.W., Klose, W., McCleskey, T., Toomey, J.K., 2009. Fossil invertebrates of the U.S. Naval Station Guantanamo Bay, Cuba, Part 2, Pleistocene Corals. Division of Invertebrate Paleontology, Florida Museum of Natural History, 28 pp.

Potter, E.-K., Lambeck, K., 2003. Reconciliation of sea-level observations in the western North Atlantic during the last glacial cycle. Earth Planet. Sci. Lett. 217, $171-181$.

Prentice, C.S., Mann, P., Crone, A.J., Gold, R.D., Hudnut, K.W., Briggs, R.W., Koehler, R.D., Jean, P., 2010. Seismic hazard of the Enriquillo-Plantain Garden fault in Haiti inferred from palaeoseismology. Nat. Geosci. 3, 789-793.

Rojas-Agramonte, Y., Neubauer, F., Handler, R., Garcia-Delgado, D.E., Friedl, G.,
Delgado-Damas, R., 2005. Variation of palaeostress patterns along the Oriente transform wrench corridor, Cuba: significance for Neogene-Quaternary tectonics of the Caribbean realm. Tectonophysics 396, 161-180.

Schellmann, G., Radtke, U., 2004. A revised morpho- and chronostratigraphy of the Late and Middle Pleistocene coral reef terraces on southern Barbados (Wes Indies). Earth-Science Rev. 64, 157-187.

Shinn, E.A., Lidz, B.H., Kindinger, J.L., Hudson, J.H., Halley, R.B., 1989. Reefs of Florida and the Dry Tortugas: a Guide to the Modern Carbonate Environments of the Florida Keys and the Dry Tortugas. U.S. Geological Survey, St. Petersburg, Florida, p. 53.

Smith, D.A., Small, H.J., 1999. The CARIB97 high-resolution geoid height model for the Caribbean Sea. J. Geodesy 73, 1-9.

Speed, R.C., Cheng, H., 2004. Evolution of marine terraces and sea level in the last interglacial, Cave Hill, Barbados. Geol. Soc. Am. Bull. 116, 219-232.

Stein, M., Wasserburg, G.J., Aharon, P., Chen, J.H., Zhu, Z.R., Bloom, A., Chappell, J., 1993. TIMS U-series dating and stable isotopes of the last interglacial event in Papua New Guinea. Geochimica Cosmochimica Acta 57, 2541-2554.

Stirling, C.H., Esat, T.M., Lambeck, K., McCulloch, M.T., 1998. Timing and duration of the Last Interglacial: evidence for a restricted interval of widespread coral reef growth. Earth Planet. Sci. Lett. 160, 745-762.

Szabo, B.J., $1979 .{ }^{230} \mathrm{Th},{ }^{231} \mathrm{~Pa}$, and open system dating of fossil corals and shells. J. Geophys. Res. 84, 4927-4930.

Szabo, B.J., Ward, W.C., Weidie, A.E., Brady, M.J., 1978. Age and magnitude of the late Pleistocene sea-level rise on the eastern Yucatan Peninsula. Geology 6, $713-715$.

Taber, S., 1934. Sierra Maestra of Cuba, part of the northern rim of the Bartlett Trough. Geol. Soc. Am. Bull. 45, 567-620.

Taggart, B.E., Joyce, J., 1990. Radiometrically dated marine terraces on northwestern Puerto Rico. In: Larue, D.K., Draper, G. (Eds.), Transactions of the $12^{\text {th }}$ Caribbean Geological Conference. Miami Geological Society, pp. 248-258.

Tamisiea, M.E., Mitrovica, J.X., 2011. The moving boundaries of sea level change: understanding the origins of geographic variability. Oceanography 24, 24-39.

Taylor, F.W., Mann, P., 1991. Late Quaternary folding of coral reef terraces, Barbados. Geology 19, 103-106.

Thompson, W.G., Goldstein, S.L., 2005. Open-system coral ages reveal persistent suborbital sea-level cycles. Science 308, 401-404.

Thompson, W.G., Spiegelman, M.W., Goldstein, S.L., Speed, R.C., 2003. An opensystem model for U-series age determinations of fossil corals. Earth Planet. Sci. Lett. 210, 365-381.

Thompson, W.G., Curran, H.A., Wilson, M.A., White, B., 2011. Sea-level oscillations during the last interglacial highstand recorded by Bahamas corals. Nat. Geosci. 4, 684-687.

Toscano, M.A., Rodriguez, E., Lundberg, J., 1999. Geologic investigation of the late Pleistocene Jaimanitas Formation: Science and society in Castro's Cuba. In: Curran, H.A., Mylroie, J.E. (Eds.), Proceedings of the 9th Symposium on the Geology of the Bahamas and Other Carbonate Regions. Bahamian Field Station, Ltd., San Salvador, Bahamas, pp. 125-142.

Toscano, M.A., Macintyre, I.G., Lundberg, J., 2012. Last interglacial reef limestones, northeastern St. Croix, US Virgin Islands-evidence of tectonic tilting and subsidence since MIS 5.5. Coral Reefs 31, 27-38.

Vacher, H.L., Rowe, M.P., 1997. Geology and hydrogeology of Bermuda. In: Vacher, H.L., Quinn, T.M. (Eds.), Geology and Hydrology of Carbonate Islands. Developments in Sedimentology, vol. 54. Elsevier, Amsterdam, pp. 35-90.

Vaughn, T.W., 1919. Fossil corals from Central America, Cuba, and Porto Rico, with an account of the American Tertiary, Pleistocene, and Recent coral reefs. U. S. Natl. Mus. Bull. 103, 189-524.

Veeh, H.H., 1966. ${ }^{230} \mathrm{Th} /{ }^{238} \mathrm{U}$ and ${ }^{234} \mathrm{U} /{ }^{238} \mathrm{U}$ ages of Pleistocene high sea-level stand. J. Geophys. Res. 71, 3379-3386.

Wehmiller, J.F., Simmons, K.R., Cheng, H., Edwards, R.L., Martin-McNaughton, J., York, L.L., Krantz, D.E., Shen, C.-C., 2004. Uranium-series coral ages from the U.S Atlantic Coastal Plain-the "80 ka problem" revisited. Quat. Int. 120, 3-14.

White, B., Curran, H.A., Wilson, M.A., 1998. Bahamian coral reefs yield evidence of a brief sea-level lowstand during the last interglacial. Carbonates Evaporites 13, $10-22$.

Wilson, M.A., Curran, H.A., White, B., 1998. Paleontological evidence of a brief global sea-level event during the last interglacial. Lethaia 31, 241-250.

Winter, A., Paul, A., Nyberg, J., Oba, T., Lundberg, J., Schrag, D., Taggart, B., 2003. Orbital control of low-latitude seasonality during the Eemian. Geophys. Res. Lett. 30, 1163,. https://doi.org/10.1029/2002GL016275.

Woodring, W.P., Brown, J.S., Burbank, W.S., 1924. Geology of the Republic of Haiti. Haiti Department of Public Works, Port-au-Prince, p. 631.

Woodroffe, C.D., Stoddart, D.R., Harmon, R.S., Spencer, T., 1983. Coastal morphology and late Quaternary history, Cayman Islands, West Indies. Quat. Res. 19, 64-84. 